\title{
Working-Class Power, Capitalist-Class Interests, and Class Compromise ${ }^{1}$
}

\author{
Erik Olin Wright \\ University of Wisconsin
}

\begin{abstract}
This article proposes a general theoretical framework for understanding the concept of "class compromise" in terms of a "reverseJ" model of the relationship between the associational power of workers and the interests of capitalists: increases in working-class power adversely affect capitalist-class interests until such power crosses some intermediate threshold beyond which further increases in working-class power are potentially beneficial to capitalists' interests. This article argues that the reverse-J curve is itself the result of two distinct kinds of effects of workers' power on capitalists' interests: one, a negative effect, in which workers' power undermines the capacity of capitalists to unilaterally make various kinds of decisions, and the second, a positive effect, in which workers' power helps capitalists solve the various kinds of collective action problems they face.
\end{abstract}

The concept of "class compromise" invokes three quite distinct images. In the first, class compromise is an illusion. Leaders of working-class organizations - especially unions and parties — strike opportunistic deals with the capitalist class that promise general benefits for workers but that, in the end, are largely empty. Class compromises are, at their core, one-sided capitulations rather than reciprocal bargains embodying mutual concessions.

In the second image, class compromises are like stalemates on a battlefield. Two armies of roughly similar strength are locked in battle. Each is sufficiently strong to impose severe costs on the other; neither is strong enough to definitively vanquish the opponent. In such a situation of stalemate, the contending forces may agree to a "compromise": to refrain from mutual damage in exchange for concessions on both sides. The concessions

\footnotetext{
${ }^{1}$ I would like to thank Samuel Bowles, Andrew Mitchner, Michael Burawoy, Joel Rogers, and Robert Boyer for their extremely constructive criticisms of earlier drafts of this article. Direct correspondence to Erik Olin Wright, Department of Sociology, University of Wisconsin, 1180 Observatory Drive, Madison, Wisconsin 53706. E-mail: Wright@ssc.wisc.edu
}

(C) 2000 by The University of Chicago. All rights reserved. 0002-9602/2000/10504-0002\$02.50 
are real, not phoney, even if they are asymmetrical. Still, they do not constitute a process of real cooperation between opposing class forces. This outcome can be referred to as a "negative class compromise."

The third image sees class compromise as a form of mutual cooperation between opposing classes. This is not simply a situation of a balance of power in which the outcome of conflict falls somewhere between a complete victory or a complete defeat for either party. Rather, here there is a possibility of a non-zero-sum game between workers and capitalists, a game in which both parties can improve their position through various forms of active, mutual cooperation. This outcome can be called a "positive class compromise."

The basic objective of this article is to explore the theoretical logic of positive class compromises and to propose a general model of the conditions conducive to them in developed capitalist societies. The article will not attempt a systematic empirical investigation, although empirical illustrations will be used to clarify elements of the model. The premise of the analysis is that so long as capitalism in one form or another is the only historically available way of organizing an economy, a positive class compromise - if it is achievable - will generally constitute the most advantageous context for the improvement of the material interests and life circumstances of ordinary people. If one is interested in advancing such interests, therefore, it is important to understand the conditions that facilitate or hinder the prospects for positive class compromise.

The central argument I will make is that the possibilities for stable, positive class compromise generally hinge on the relationship between the associational power of the working class and the material interests of capitalists. The conventional wisdom among both neoclassical economists and traditional Marxists is that, in general, there is an inverse relationship between these two variables: increases in the power of workers adversely affect the interests of capitalists (see fig. 1). The rationale for this view is straightforward for Marxist scholars: since the profits of capitalists are closely tied to the exploitation of workers, the material interests of workers and capitalists are inherently antagonistic. Anything that strengthens the capacity of workers to struggle for and realize their interests, therefore, negatively affects the interests of capitalists. The conventional argument by neoclassical economists is somewhat less straightforward, for they deny that in a competitive equilibrium workers are exploited by capitalists. Nevertheless, working-class associational power is seen as interfering with the efficient operation of labor markets by making wages harder to adjust downward when needed and by making it harder for employers to fire workers. Unions and other forms of working-class power are seen as forms of monopolistic power within markets, and like all such practices, they generate monopoly rents and inefficient allocations. As a result, unionized 

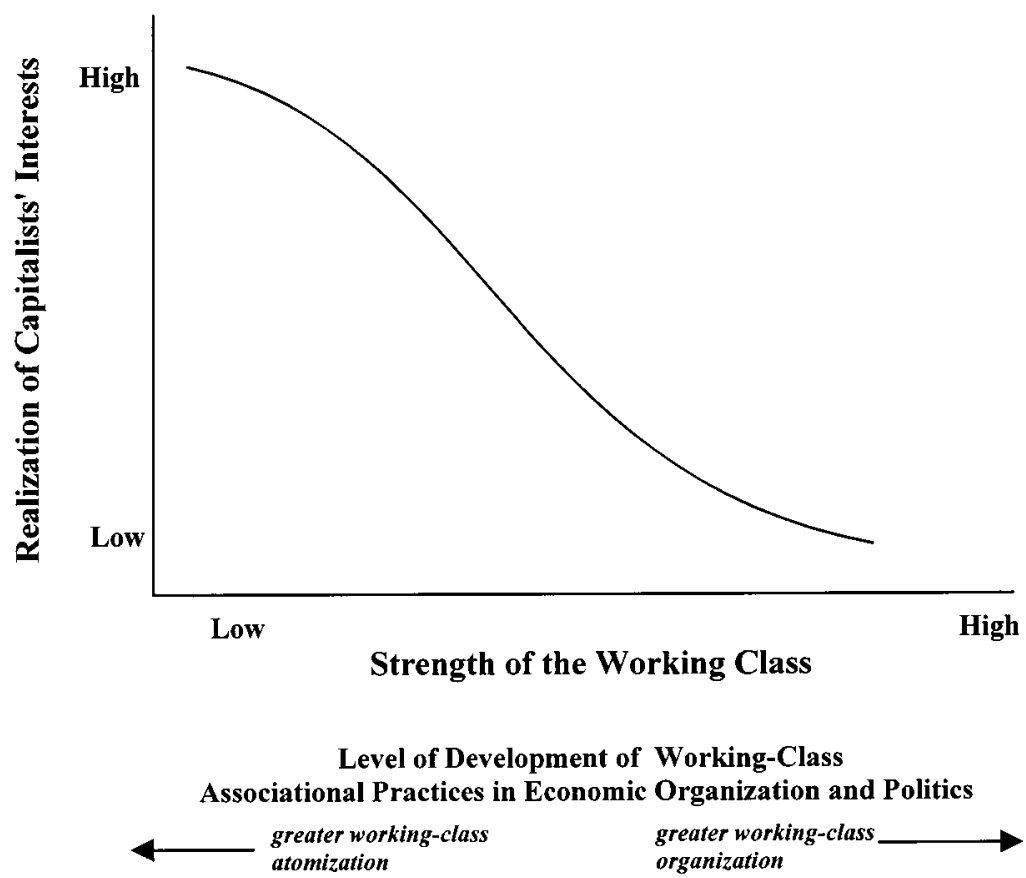

FIG. 1.-Conventional view of the relationship between working-class strength and capitalist-class interests.

workers are able to extort a monopoly rent in the form of higher wages at the expense of both capitalists and nonunionized workers.

This article explores an alternative understanding of the relationship between workers' power and capitalists' interests: instead of an inverse relationship, this alternative postulates a curvilinear reverse- $J$ relationship (see fig. 2). ${ }^{2}$ As in the conventional wisdom, capitalist-class interests are best satisfied when the working class is highly disorganized: when workers compete with each other in an atomized way and lack significant forms of associational power. As working-class power increases, capitalist-class interests are initially adversely affected. However, once workingclass power crosses some threshold, working-class associational power begins to have positive effects on capitalists' interests. As we shall see in more detail below, these conditions allow for significant gains in productivity and rates of profit due to such things as high levels of bargained

${ }^{2}$ The reverse-J shaped relationship between working-class power and capitalists' interests was first suggested to me in an article by Joel Rogers (1990). 


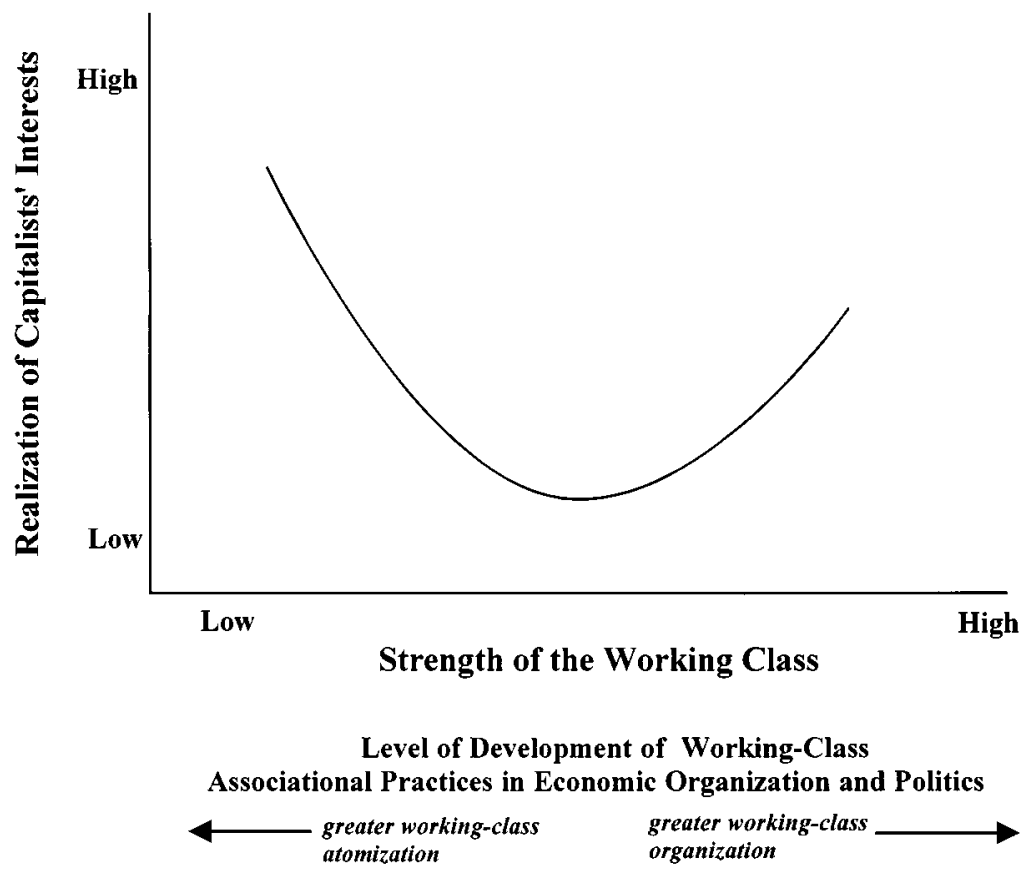

FIG. 2.-Curvilinear relationship between working-class strength and capitalistclass interests.

cooperation between workers and capitalists, rationalized systems of skill upgrading and job training, enhanced capacity for solving macroeconomic problems, and a greater willingness of workers to accept technological change given the relative job security they achieve because of union protections. The upward-bending part of the curve, where increases in working-class power have positive effects on capitalist-class interests, generates conditions for positive class compromise. The goal of this article, then, is to elaborate a general theoretical model of the causal processes underlying the relation presented in figure 2 .

The first section of this article briefly defines the core concepts used in the analysis. The second section situates the problem of positive class compromise within a broader literature on interclass cooperation, labor relations, and economic governance. The next section then frames the problem of class compromise in terms of various possible game-theory models of the interactions of workers and capitalists. With this gametheoretic background, the fourth section elaborates general theoretical arguments about the underlying mechanisms for the reverse-J model of positive class compromise. The last section concludes the article with a 
somewhat speculative discussion of the impact of globalization on the prospects of class compromise.

\section{CORE CONCEPTS AND METHODOLOGICAL ISSUES}

Some of the concepts used in this article do not have transparent meanings. In particular, the concepts of "class," "interests," and "power" are all highly contested. I will not attempt to elaborate analytically precise definitions of any of these concepts here, but some brief clarifications are necessary.

Class. - The meaning of class and its related concepts—class structure, class struggle, class formation, class compromise - can be analyzed at various levels of abstraction. For some purposes, it is important to deploy a highly differentiated class concept that elaborates a complex set of concrete locations within class structures. My work on the problem of the "middle class" and "contradictory locations within class relations" would be an example of such an analysis (Wright 1985, 1997). For some problems, the causal processes cannot be properly studied without specifying a range of fine-grained differentiations and divisions within classes on the basis of such things as sector, status, gender, and race. For other purposes, however, it is appropriate to use a much more abstract, simplified class concept, revolving around the central polarized class relation of capitalism: capitalists and workers. This is the class concept I will use in most of this article.

In a stylized Marxian manner, I will define capitalists as those people who own and control the capital used in production and workers as all employees excluded from such ownership and control. In this abstract analysis of class structure, I will assume that these are mutually exclusive categories. There is thus no middle class as such. No workers own any stock. Executives, managers, and professionals in firms are either amalgamated into the capitalist class by virtue of their ownership of stock and command of production, or they are simply part of the "working class" as employees. Of course, this is unrealistic. My claim, however, is that this abstract, polarized description of class relations in capitalism can still be useful in clarifying real mechanisms that actual actors face and is thus a useful point of departure for developing a theory of class compromise. ${ }^{3}$

\footnotetext{
${ }^{3}$ The claim that this abstract polarized concept of class is analytically useful may be controversial. Given that actual capitalist firms engaging in complex strategies and bargaining with their employees encounter considerable heterogeneity, and this heterogeneity in fact does matter for the optimal profit maximizing strategy of the firm, it may seem illegitimate to bracket such complexity in favor of a simple model of capital and labor. As in all attempts at elaborating theoretical models, the appropriate level of abstraction is a matter of contestation.
} 
Interests. - Throughout this article, our attention will be restricted to what can be narrowly termed the "material interests" of people by virtue of their class location, or what I will refer to in shorthand as "class interests." In general, I will make two radical simplifying assumptions about the nature of these interests: first, that class interests can be reduced to a single quantitative dimension so that one can talk about the extent to which the interests of the members of a class are realized; and second, that all people in a given class location share the same class interests. Both of these assumptions are problematic when we study concrete capitalist societies but, as in the adoption of a simple polarized class structure concept, are useful simplifications for the present analytical purposes.

Power.-Like "interests," "power" is used in many different ways in social theory. In the context of class analysis, power can be thought of as the capacity of individuals and organizations to realize class interests. Insofar as the interests of people in different classes-say workers and capitalists - are opposed to each other, this implies that the capacity of workers to realize their class interests depends in part on their capacity to counter the power of capitalists. Power, in this context, is thus a relational concept.

In this article, our concern is mainly with what I will term workingclass "associational" power - the various forms of power that result from the formation of collective organizations of workers. This includes such things as unions and parties but may also include a variety of other forms, such as works councils or forms of institutional representation of workers on boards of directors in schemes of worker codetermination, or even, in certain circumstances, community organizations. Associational power is to be contrasted with what can be termed "structural power"-power that results simply from the location of workers within the economic system. The power of workers as individuals that results directly from tight labor markets or from the strategic location of a particular group of workers within a key industrial sector would constitute instances of structural power. While such structural power may itself influence associational power, I will focus in this article on associational power as such.

The models examined here do not directly concern the role of associational power of capitalists in the formation of class compromise. As the literature on neocorporatism has pointed out, there are certain institu-

\footnotetext{
${ }^{4}$ When I speak of "class interests," I will always mean the interests of people determined by their location in the class structure. I do not believe that classes as collective entities have "interests" in a literal sense. Of course, individuals may have interests in the strength of the collective organizations of classes, and the class interests of individuals may be contingent upon the security of the interests of other members of the same class, but this still does not mean that classes as collectivities have "interests."
} 
tional settings of class compromise in which the associational power of employers plays a pivotal role (Streeck and Schmitter 1985; Streeck 1992; Pontusson 1997), and there will be places in the discussion where reference will be made to the role of such associations. Our concern, however, is not with capitalists' associational power, as such, but with the ways in which working-class associational power has an impact on the interests of capitalists.

There is no implication in the analysis that workers' associational power is entirely exogenous to the processes investigated. While I will concentrate on the ways in which increases in workers' power can positively benefit capitalists' interests, it may also be the case that part of the explanation for the level of workers' associational power is precisely the existence of this beneficial effect and, conversely, that the erosion of such beneficial effects may itself contribute to the decline of workers' power. To the extent that the intensity of resistance by capitalists, individually and collectively, to workers' attempts at creating and sustaining associational power itself partially depends upon the potential benefits to capital of such power, the extent of workers' power will in part be a function of capitalists' interests. In any case, this article does not attempt to develop a dynamic theory of the causes of working-class power but merely of the effects of such power on capitalists' interests.

\section{Sites of Class Compromise}

Class struggle and compromise do not occur within an amorphous "society" but within specific institutional contexts-firms, markets, states. The real mechanisms that generate the reverse-J curve in figure 2 are embedded in such institutional contexts. Three institutional spheres within which class struggles occur and class compromises are forged are particularly important and are defined below.

The sphere of exchange.-This concerns, above all, the labor market and various other kinds of commodity markets. In some situations, financial markets may also be an arena within which class conflicts occur and class compromises are forged.

The sphere of production. - This concerns what goes on inside of firms once workers are hired and capital invested. Conflicts over the labor process and technology are the characteristic examples.

The sphere of politics. - Class conflict and class compromise also occur within the state over the formation and implementation of state policies and the administration of various kinds of state-enforced rules.

There is a rough correspondence between each of these institutional spheres of class conflict and class compromise and characteristic kinds of working-class collective organizations: labor unions are the characteristic 
associational form for conflict and compromise in the sphere of exchange; works councils and related associations are the characteristic form within the sphere of production; and political parties are the characteristic form within the sphere of politics.

The central task of our analysis, then, is to examine the mechanisms that enable these different forms of working-class associational powerunions, works councils, parties-to forge positive class compromises within the spheres of exchange, production, and politics.

\section{SITUATING THE CONCEPT OF CLASS COMPROMISE}

In the most abstract and general terms, class compromise-whether positive or negative - can be defined as a situation in which some kind of quid pro quo is established between conflicting classes in which, in one way or another, people in each class make "concessions" in favor of the interests of people in the opposing class. ${ }^{5}$ The "compromise" in class compromise is a compromise of class-based interests-members of each class give up something of value. Class compromise is thus always defined against a counterfactual in which such concessions are not made. Typically, this is a situation in which the use of threats, force, and resistance plays a more prominent active role in class interactions.

Defined in this way, the idea of class compromise is closely linked to Gramsci's (1971) concept of "hegemony." Gramsci uses the concept of hegemony to distinguish two general conditions of capitalist society. In a nonhegemonic system, capitalist-class relations are reproduced primarily through the direct, despotic use of coercion. In a hegemonic system, in contrast, class relations are sustained in significant ways through the $a c$ tive consent of people in the subordinate classes. Coercion is still present as a background condition-hegemony is "protected by the armor of coercion" in Gramsci's famous phrase-but it is not continually deployed actively to control people's actions. To quote Adam Przeworski (1985, p. 136), "A hegemonic system is, for Gramsci, a capitalist society in which capitalists exploit with consent of the exploited." For hegemony to be sustained over time, there must be, in Przeworski's (1985, pp. 133-69) apt expression, "material bases of consent." This, in turn, requires some sort of class compromise: "the fact of hegemony presupposes that account be taken of the interests and the tendencies of the groups over which hegemony is to be exercised, and that a certain compromise equilibrium should

\footnotetext{
${ }^{5}$ Although the actual term "class compromise" appears mainly within the Marxian tradition of social theory, the substantive idea has much broader currency. I will not limit the discussion here to instances where the term is explicitly deployed.
} 


\begin{tabular}{|c|c|c|c|}
\hline & & Form of $C$ & Compromise \\
\hline & & NEGATIVE & POSITIVE \\
\hline $\begin{array}{l}\text { Strategic } \\
\text { Basis of } \\
\text { Class }\end{array}$ & $\begin{array}{l}\text { INDIVIDUAL } \\
\text { STRATEGIES } \\
\text { WITHOUT } \\
\text { ASSOCIATIONAL } \\
\text { POWER }\end{array}$ & $\begin{array}{l}\text { Effort-promoting } \\
\text { efficiency wages }\end{array}$ & $\begin{array}{l}\text { Loyalty-promoting } \\
\text { internal labor } \\
\text { markets }\end{array}$ \\
\hline Compromise & $\begin{array}{l}\text { ASSOCIATIONAL } \\
\text { POWER }\end{array}$ & $\begin{array}{l}\text { Collective } \\
\text { bargaining as } \\
\text { mutual } \\
\text { concessions }\end{array}$ & $\begin{array}{l}\text { Positive-sum social } \\
\text { pacts: Keynesianism; } \\
\text { neocorporatism }\end{array}$ \\
\hline
\end{tabular}

FIG. 3.-The conceptual space of class compromise

be formed-in other words, that the leading group should make sacrifices of an economic-corporate kind" (Gramsci 1971, p. 161).

Gramsci developed the concept of class compromise in only a sketchy and fragmented form. The scholar who has most systematically and rigorously elaborated this concept is Przeworski. Przeworski makes the central quid pro quo of class compromise explicit: "Given the uncertainty whether and how capitalists would invest profits, any class compromise must consist of the following elements: workers consent to profit as an institution, that is, they behave in such a manner as to make positive rates of profit possible; and capitalists commit themselves to some rate of transformation of profits into wage increases and some rate of investment out of profits" (Przeworski 1985, p. 182).

Przeworski's formulation here is close to what I have called "negative class compromise," insofar as he emphasizes the abstention of workers from levels of militancy that would interfere with the production of profits in exchange for material concessions by capitalists. Elsewhere, he explores the positive face of class compromise in his analysis of how Keynesianism, backed by organized labor and social-democratic parties in the advanced capitalist countries in the post-World War II period, expanded aggregate demand in ways that ultimately benefited capitalists as well as laborers (Przeworski 1985, pp. 205-11). The model of class compromise that I develop in this article can be viewed as an extension and reformulation of Przeworski's core idea through the elaboration of this positive side of class compromise.

Before examining the details of this model, it will be useful to situate it within a broader array of alternative treatments of the problem of cooperation and compromise among class actors. Figure 3 organizes this con- 
ceptual space along two dimensions: first, whether the strategic basis of class compromise is primarily individual strategies or associational power, and second, whether the form of class compromise is primarily negative or positive. The four categories generated by these two dimensions constitute distinctive ways in which interclass cooperation and compromise can be generated.

The paradigmatic case of negative class compromise grounded in individual strategies is so-called "efficiency wages." An efficiency wage is a king of "employment rent" — a wage premium above the equilibrium "market-clearing wage"-paid by an employer as part of a strategy to reduce shirking on the part of employees. As elaborated by Bowles (1985) and Bowles and Gintis (1990, 1998, pp. 36-39), building on the earlier work of Alchian and Demsetz (1972), Shapiro and Stiglitz (1984), Ackerlof and Yellen (1986), Williamson (1985), and others, employers face a problem of the "extraction of labor effort" from workers-getting workers to work harder than they want to do spontaneously-since the labor contract is neither complete nor costlessly enforceable. Employers face a trade-off between spending more money on improving the effectiveness of monitoring or paying higher employment rents. Such efficiency wages are a form of negative class compromise insofar as the higher wages are an alternative to more purely coercive strategies by employers in the face of strategies of resistance (shirking) by individual workers. ${ }^{7}$

Positive class compromises can also emerge out of individual strategic interactions between employers and workers. Perhaps the best example is internal labor markets (ILMs). ${ }^{8}$ Although, as in the case of efficiency

${ }^{6}$ There are some treatments of efficiency wages that treat them more as a form of positive than of negative class compromise. For example, Akerlof (1982) sees such arrangements less as a concession in response to a form of individual resistanceshirking - and more as a way of improving generalized morale through a kind of normatively grounded "gift exchange." The implication is that efficiency wages underwrite active cooperation.

${ }^{7}$ Investigations of institutional arrangements like efficiency wages, especially by economists, generally do not explicitly analyze them in class terms. From the point of view of standard neoclassical economics, such arrangements are simply profit-maximizing strategies of employers designed to minimize the transaction costs associated with the inherent human tendency, in Williamson's (1985, p. 47) expression, for people to be "self-interest seeking with guile." Bowles and Gintis (1990, 1998), in contrast, firmly situate the problem of efficiency wages in the class relations of capitalist production, arguing that in firms where workers were also owners, mutual monitoring would significantly replace the need for efficiency wages.

${ }^{8}$ Some discussions of internal labor markets treat them primarily as examples of negative class compromise, emphasizing the ways in which ILMs are instigated to divide the working class, weaken unions, and in other ways enhance capitalist control over labor (see, e.g., Gordon [1976]; Edwards [1979]). Others treat ILMs strictly as a question of solving problems of internal efficiency, typically linked to information costs and the problem of retaining skilled employees, without systematic reference to the 
wages, internal labor markets may increase the effectiveness of negative sanctions by employers since workers within internal labor markets have more to lose if they are disciplined or fired (Bartlett 1989, pp. 135-37), most analyses of internal labor markets emphasize the ways they are designed to elicit active cooperation rooted in loyalty and commitment of the individual to the interests of the organization. This is one of the central themes in the extensive literature on Japanese work organization (Dore 1973; Ouchi 1981; Aoki 1988), but it has also figured in the broader analysis of the internal organization of capitalist firms (Williamson 1985; Foulkes 1980; Sorensen 1994) and even in some more abstract analyses of class relations as such. ${ }^{9}$

Most discussions of class conflict and class compromise pay relatively little attention to these forms of interclass compromise, positive or negative, generated by the strategies of individuals. Rather, they focus on the ways class compromises are forged through class struggles rooted in classbased associational power. Analyses of negative class compromise emerging from class struggle are particularly prominent in the Marxist tradition. ${ }^{10}$ If the interests of workers and capitalists are inherently antagonistic and polarized, then it would appear that whatever compromises emerge from class struggle simply reflect balances of power between contending forces (for an illustrative example, see Kotz 1994, p. 55).

The idea of positive class compromise generated by organized class struggle sits less comfortably within the Marxist tradition but is at the core of the large literature on social democracy and neocorporatism (e.g., Korpi 1983; Soskice 1990; Esping-Andersen 1990) and considerable recent work in economic sociology that focuses on the problem of the economic

class character of these efficiency considerations (see, e.g., Doeringer and Piore 1985; Greenwald 1979; Waldman 1984).

${ }^{9}$ Goldthorpe's (1982) concept of the "service class" revolves around the problems employers face when their employees sell a "service" rather than simply "labor." The creation of career ladders built around prospective rewards that create a longer time horizon of commitment for such employees is at the core of his analysis of the specificity of this employment relation. My analysis of "loyalty rents" for managerial class locations (Wright 1997, p. 21) also emphasizes the problem of creating deeper commitments for certain categories of employees by anchoring their jobs in career ladders. In both of these treatments of class relations, internal labor markets are created as responses to the strategies of individuals within firms.

${ }^{10}$ Such views, however, are not restricted to Marxists. John R. Commons's ([1950] 1970) conception of collective bargaining, for example, is essentially a conception of negative class compromise insofar as he felt it was necessary to avoid a mutually destructive "class war." Unions might be in the general "public interest," but Commons does not claim that unionization and collective bargaining as such are directly beneficial to capitalists: "The unions and administrative commissions were organized to restrain corporations, also in the public interest, from abuse of their corporate power over individuals" (Commons 1970, p. 132). 
performance of different capitalist economies (e.g., Streeck and Schmitter 1985; Kenworthy 1995; Gordon 1996; Crouch and Streeck 1997). As Rogers and Streeck (1994, p. 130) put it: "The democratic left makes progress under capitalism when it improves the material well-being of workers, solves a problem for capitalists that capitalists cannot solve for themselves, and in doing both wins sufficient political cachet to contest capitalist monopoly on articulating the 'general interest.'”

The classic form of this argument is rooted in the Keynesian strand of macroeconomic theory. Full employment, insofar as it implies high levels of capacity utilization and higher aggregate demand for the products of capitalist firms, potentially serves the interests of capitalists. But it also risks a profit squeeze from rapidly rising wages and spiraling levels of inflation. Keynes himself recognized this as a serious problem: "I do not doubt that a serious problem will arise as to how wages are to be restrained when we have a combination of collective bargaining and full employment" (cited in Glynn 1995, p. 37). The emergence and consolidation in a number of countries of strong, centralized unions capable of imposing wage restraint on both workers and employers was perhaps the most successful solution to this problem. In this sense, a powerful labor movement need not simply constitute the basis for a negative class compromise, extracting benefits for workers through threats to capital. If a labor movement is sufficiently disciplined, particularly when it is articulated to a sympathetic state, it can positively contribute to the realization of capitalists' interests by helping to solve macroeconomic problems.

The best-known empirical study to explore the curvilinear relationship between workers' power and capitalists' interests is Calmfors and Driffill's (1988) study of the effects of union centralization on economic performance (see also Pohjola 1992; Freeman 1988; Calmfors 1993; Garrett 1998, pp. 26-50; Rowthorn 1992). ${ }^{11}$ Following Mancur Olson's (1982) original idea, Calmfors and Driffill (1988, p. 15) argue that "organized interests may be most harmful when they are strong enough to cause major disruptions but not sufficiently encompassing to bear any significant fraction of the costs for society of their actions in their own interests." They demonstrate that among 18 OECD countries, during the period 1963-85, economic performance measured in a variety of ways was best among those countries with either highly centralized or highly decentralized wage bargaining structures, and worst in the intermediary countries. A similar result, using different kinds of indicators, is found in Hicks and Kenwor-

\footnotetext{
${ }^{11}$ Strictly speaking, Calmfors and Driffill (1988) study the relationship between workers' power and various measures of general economic "performance" rather than capitalists' interests as such, but in the context of their arguments, this can reasonably be taken as an indicator of capitalists' interests.
} 
thy's (1998) study of the impact of various forms of cooperative institutions on economic performance. They observe a strong curvilinear relationship between union density and real per capita gross domestic product growth for the period 1960-89 in 18 OECD countries, indicating that countries with either low or high union density had higher growth rates during these three decades than countries with middling levels of union density.

The rest of this article will attempt to elaborate theoretically this curvilinear model of positive class compromise. The next section begins by framing the problem through a game-theoretic perspective on strategic conflicts between workers and capitalists and then turns to the problem of the mechanisms that generate the curvilinear relationship between workers' power and capitalists' interests.

\section{STRATEGIC GAMES AND CLASS COMPROMISE}

In order to analyze the relationship of working-class associational power to capitalist-class interests and class compromise, we must first more rigorously understand the strategic contexts for the conflicts of interests of workers and capitalists. We will do this by exploring a series of strippeddown, game-theory models based on a highly simplified picture of class conflict in which workers and capitalists each face a binary strategic choice: to cooperate with the other class or to actively oppose its interests. Because the actors in this game have qualitatively different roles in the system of production, the meaning of "cooperate" and "oppose" are different for each. As summarized in figure 4, for workers to cooperate with capitalists means that they work hard and diligently in order to maximize the capitalists' rate of profit. Workers rely primarily on market mechanisms (changing jobs) as a way of expressing dissatisfaction with pay or working conditions; while they may have collective associations (unions), they do not engage in active struggles to collectively pressure capitalists for improvements; nor do they engage in political struggle to advance workers' interests against those of capitalists. To oppose capitalists is to struggle against them, individually and collectively, in order to raise worker incomes and enhance the extent to which workers control their own labor effort, and thus to minimize the extent to which capitalists exploit and control workers. This includes political struggles to expand worker rights and their capacity to organize collective associations. For capitalists, cooperation with workers means paying workers as much as is possible, compatible with maintaining a rate of profit sufficient to reproduce the firm; accepting workers' organizations (unions and parties) and responding positively to worker demands over working conditions; and moderating their own consumption in favor of employment-generating 

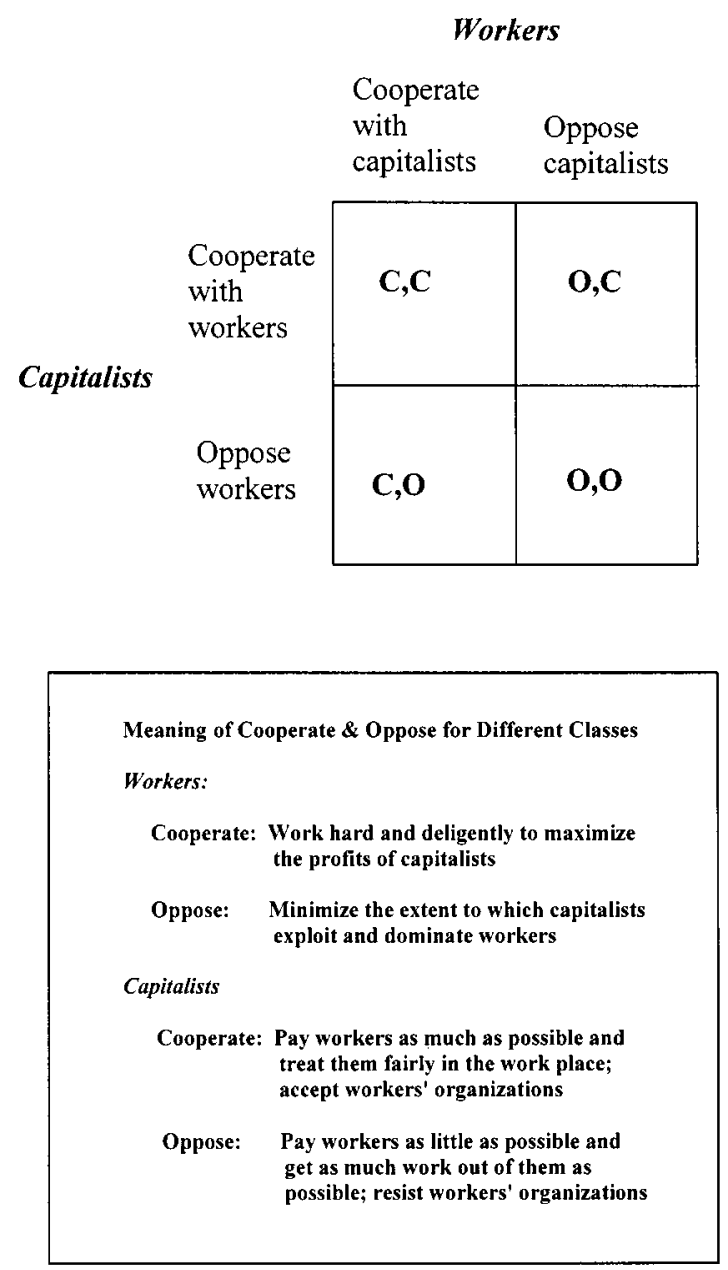

FIG. 4.-Strategic options for workers and capitalists

investment. To oppose workers' interests means paying them as little as possible, given market and technological constraints; getting as much labor as possible out of workers; and resisting worker organizations. As in the case of workers, such opposition includes political action such as opposing unemployment benefits and welfare safety nets, which raise the reservation wage, and supporting restrictive labor laws that impede unionization. Taking these two alternatives for each class yields the four possible configurations of class conflict presented in figure 4 . In terms of 
these alternatives, "positive class compromise" constitutes the situation in which both classes agree to cooperate $(\mathrm{C}, \mathrm{C}) .{ }^{12}$

Figure 5 presents a variety of alternative ways in which the interests of workers and capitalists (their payoffs to alternative strategic combinations) might be affected by these four combinations of cooperation and opposition. Model 1 can be called a unilateral capitalist domination game. Here, the best outcome for capitalists is $(\mathrm{C}, \mathrm{O})$ : workers cooperate with capitalists (working hard, not organizing, etc.), and capitalists oppose workers (pay them only what the market dictates, oppose collective organization, etc.). The second best outcome for capitalists is mutual opposition $(\mathrm{O}, \mathrm{O})$. In this game, capitalists are sufficiently powerful relative to workers that they can punish workers at relatively little cost to themselves when workers organize against them. Workers are thus worse off under $(\mathrm{O}, \mathrm{O})$ than under unilateral workers cooperation $(\mathrm{C}, \mathrm{O})$. Struggle does not pay. In this game, therefore, $(\mathrm{C}, \mathrm{O})$ will be the equilibrium outcome: capitalists are always better off opposing workers, and given that capitalists oppose workers, workers are better off cooperating with capitalists.

Model 2 represents the standard Marxist view of class conflict in which the interests of workers and capitalists are treated in a purely inverse relation as a zero-sum pure conflict game. The optimal situation for capitalists is that they oppose the interests of workers while workers cooperate with them $(\mathrm{C}, \mathrm{O})$. The second best situation for capitalists is mutual cooperation (C,C). This, however, is less advantageous for workers than is mutual opposition $(\mathrm{O}, \mathrm{O})$. In the traditional Marxist view, because the interests of workers and capitalists are strictly polarized, it is always better for workers to struggle against capitalists - to actively oppose capitalists' interests - than to willingly cooperate. The $(\mathrm{C}, \mathrm{C})$ solution, in effect, is an illusion: "cooperative" capitalists, the argument goes, treat workers only marginally better than capitalists who actively oppose workers, but cooperative workers are much less able to force their employers to make concessions than are oppositional workers. Above all, when working-class associations actively cooperate with capitalists, they weaken their capacity for mobilization, and ultimately this invites capitalists to oppose workers' interests, thus leading $(\mathrm{C}, \mathrm{C})$ to degenerate into $(\mathrm{C}, \mathrm{O})$. The $(\mathrm{O}, \mathrm{O})$ option, therefore, generally promises a better long-term payoff for workers

\footnotetext{
${ }^{12}$ Obviously in the real world, the options are much more complex than this stark contrast-not only are there various degrees of opposition and cooperation, but a variety of qualitatively distinct forms of both. Nevertheless, for purposes of developing a general inventory of strategic contexts for class compromise in which mutual cooperation occurs, it will be useful to abstract from such complexity and examine games in which members of each class (considered either as individuals or as members of associations) make such simple, dichotomous choices.
} 

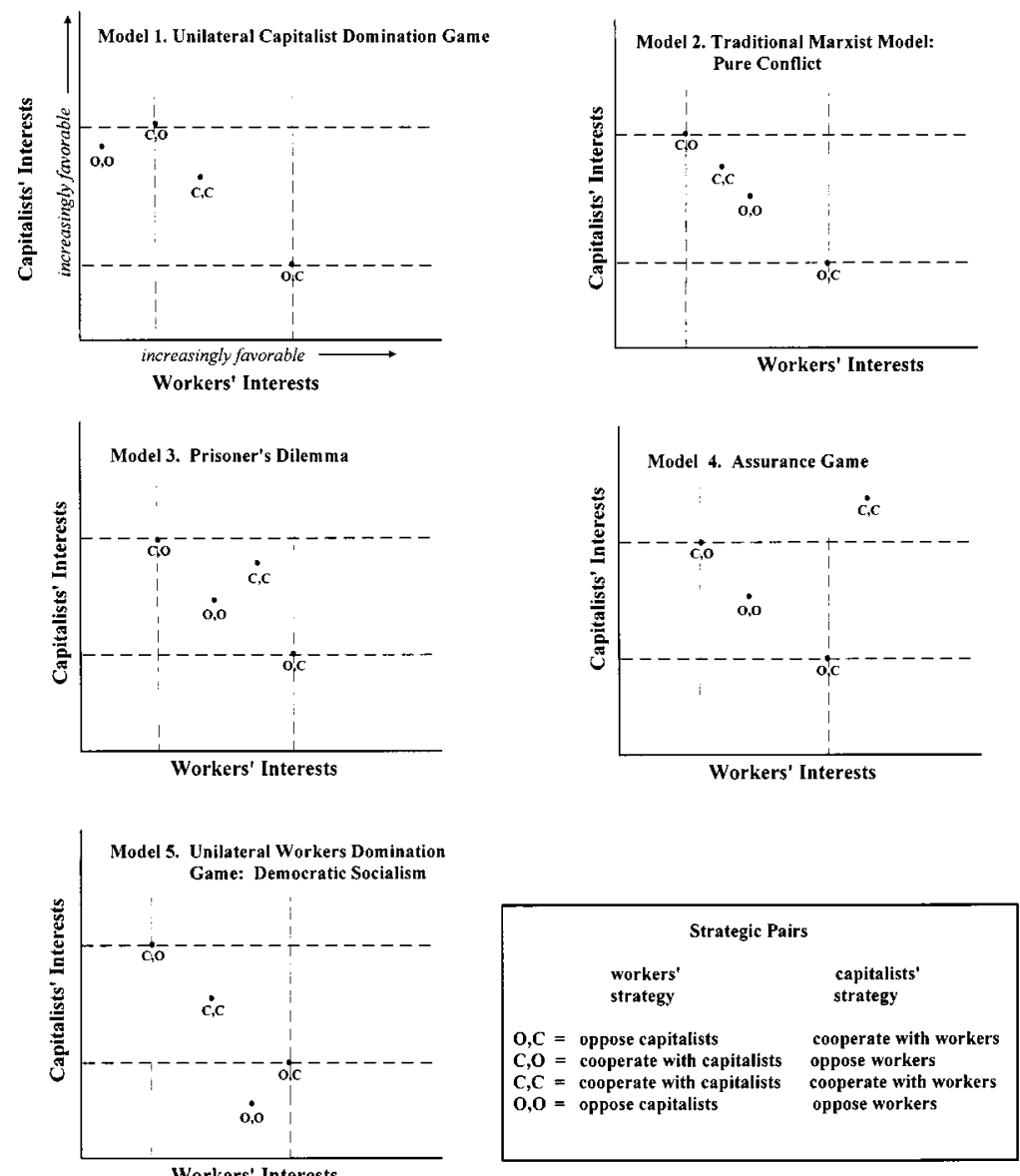

FIG. 5.-Possible strategic games and payoffs for workers and capitalists

than does the $(\mathrm{C}, \mathrm{C})$ option. As a result of such struggles, there will be moments when capitalists indeed do make concessions to workers as a result of these struggles - grant them pay raises, improve working conditions, and so on. These concessions are at best a negative class compromise-concessions in the face of struggle. For both classes in this game, opposition is better than cooperation regardless of what the other class does, and thus the equilibrium will be mutual opposition $(\mathrm{O}, \mathrm{O})$ - active forms of class struggle. ${ }^{13}$ The class struggle is much more like trench war-

${ }^{13}$ Even though mutual opposition is the equilibrium solution, model 2 is not a prisoner's dilemma for workers since in a prisoner's dilemma actors prefer mutual cooperation to mutual opposition. 
fare with occasional victories and defeats for each combatant, and perhaps periods of relatively stable balances of forces underwriting a negative class compromise.

Model 3 is the standard prisoner's dilemma game. This is a game with symmetrical payoffs for the two classes: $(C, C)$ is the second-best outcome for each class, and $(\mathrm{O}, \mathrm{O})$ is the third-best outcome. Unlike in model 1 , mutual opposition is now costly to capitalists. This implies that workers have sufficient power to be able to punish capitalists within class struggles. Unlike in model 2, however, workers are better off in mutual cooperation than in mutual opposition. Both classes are thus better off if they cooperate with each other than if they mutually oppose each other. Still, if this were a one-shot game, in standard PD fashion, the equilibrium outcome would be $(\mathrm{O}, \mathrm{O})$, since both classes could improve their payoffs by defecting from the mutual cooperation outcome. If this is a repeated game, as it would be in the real world of class interactions, then the outcome is less determinate. As Axelrod (1984) and many others have shown, in an iterated prisoner's dilemma, mutual cooperation can be a stable solution depending upon the ways opposition in future rounds of the game is used to punish players for noncooperation in earlier rounds. As the possibility of a stable (C,C) solution occurs, then positive class compromise also becomes possible.

Model 4 is a standard assurance game: for both classes, the optimal solution is mutual cooperation and unilateral cooperation is worse than mutual opposition. Unless there is reasonable confidence that the other class will cooperate, therefore, mutual cooperation is unlikely to occur. If class conflict was an assurance game, the failures of cooperation would primarily reflect a lack of enlightenment on the part of actors-they simply do not know what is good for them. This corresponds to the views of a certain kind of naive liberalism, where conflict is always seen as reflecting misunderstanding among parties and "win-win" solutions are always assumed to be possible.

A strict assurance game of this form is unlikely in capitalist economies since a situation in which capitalists can get full cooperation from workers without having to make any concessions - the $(\mathrm{C}, \mathrm{O})$ outcome — is unlikely to offer capitalists inferior payoffs to mutual cooperation. Nevertheless, there may be situations in which the $(\mathrm{C}, \mathrm{C})$ payoff moves in the direction of an assurance game and certainly situations in which the gap for both classes between $(\mathrm{C}, \mathrm{C})$ and $(\mathrm{O}, \mathrm{O})$ becomes very large.

Finally, model 5, the unilateral workers domination game, is the symmetrical model to model 1 . Here workers are sufficiently strong and capitalists are sufficiently weak that workers can force capitalists to unilaterally cooperate, including forcing them to invest in ways that enhance future earnings of workers (thus making $[\mathrm{O}, \mathrm{C}]$ preferable to $[\mathrm{C}, \mathrm{C}]$ for 
workers). This corresponds to the theoretical idea of democratic socialism: an economy within which workers effectively dominate capitalists. ${ }^{14}$

Lurking in the background of the models in figure 5 is the problem of power: the balance of power between workers and capitalists can be thought of as determining which of these strategic games is being played. As illustrated in figure 6, as working-class power increases from extremely low levels (and thus as the ability of workers to impose sanctions on capitalists increases), the $(\mathrm{O}, \mathrm{O})$ alternative in model 1 shifts downward and then to the right. This shifts the configuration in the direction of model 2 in which working-class militancy becomes sustainable and the possibility of negative class compromise-a class compromise based on the balance of force-emerges. Further increases in working-class power begin to move the $(\mathrm{C}, \mathrm{C})$ option to the right, creating the prisoner's dilemma of model 3. This sets the stage for the possibility of positive class compromise. As working-class associational power pushes $(\mathrm{C}, \mathrm{C})$ in model 3 in an upward direction toward the northeast quadrant approaching the assurance game in model 4, the possibility for a positive class compromise increases: the gains from stable, mutual cooperation increase..$^{15}$

If it were the case that increases in working-class associational power could actually push the $(\mathrm{C}, \mathrm{C})$ payoff into the northeast quadrant of this payoff matrix, then the overall relationship between workers' power and capitalists' interests would be a J-curve, not a reverse-J. That is, the highest across-game equilibrium payoff for capitalists would be the $(\mathrm{C}, \mathrm{C})$ payoff in the assurance game rather than the $(\mathrm{C}, \mathrm{O})$ payoff in the unilateral capitalist domination game, and thus it would be in the interests of capitalists to accept (and even encourage) high levels of workers' power in order to create the conditions for the assurance game to occur. It is a central substantive assumption of the Marxian framework deployed in this article that because of the underlying antagonistic, exploitative character of capitalist-class relations, this situation does not occur. Stable, mutual cooperation can still occur, but it is because, with sufficient power, the threat of opposition by workers prevents the $(\mathrm{C}, \mathrm{O})$ option from being an equilib-

\footnotetext{
${ }^{14}$ In this theoretical conception of socialism, capitalists, albeit with curtailed property rights, can exist within a socialist economy just as they existed centuries earlier within feudal society. It is another question how stable and reproducible such a structure of class relations would be. For a formal model of a sustainable socialist society within which capitalists still have some economic space, see Roemer (1994, 1996).

${ }^{15}$ As portrayed in fig. 6, working-class power only affects the $(\mathrm{O}, \mathrm{O})$ and $(\mathrm{C}, \mathrm{C})$ curves; the $(\mathrm{C}, \mathrm{O})$ and $(\mathrm{O}, \mathrm{C})$ curves remain fixed. The critical issue in the shifts across the models in fig. 5, of course, is the change in the relative location of the four payoffs, and this in principle could occur because of changes in the location of $(\mathrm{C}, \mathrm{O})$ or $(\mathrm{O}, \mathrm{C})$ as well as the mutual opposition or mutual cooperation payoffs.
} 
Transformation of the Unilateral Capitalist Domination Game into a Prisoner's Dilemma and then toward an Assurance Game
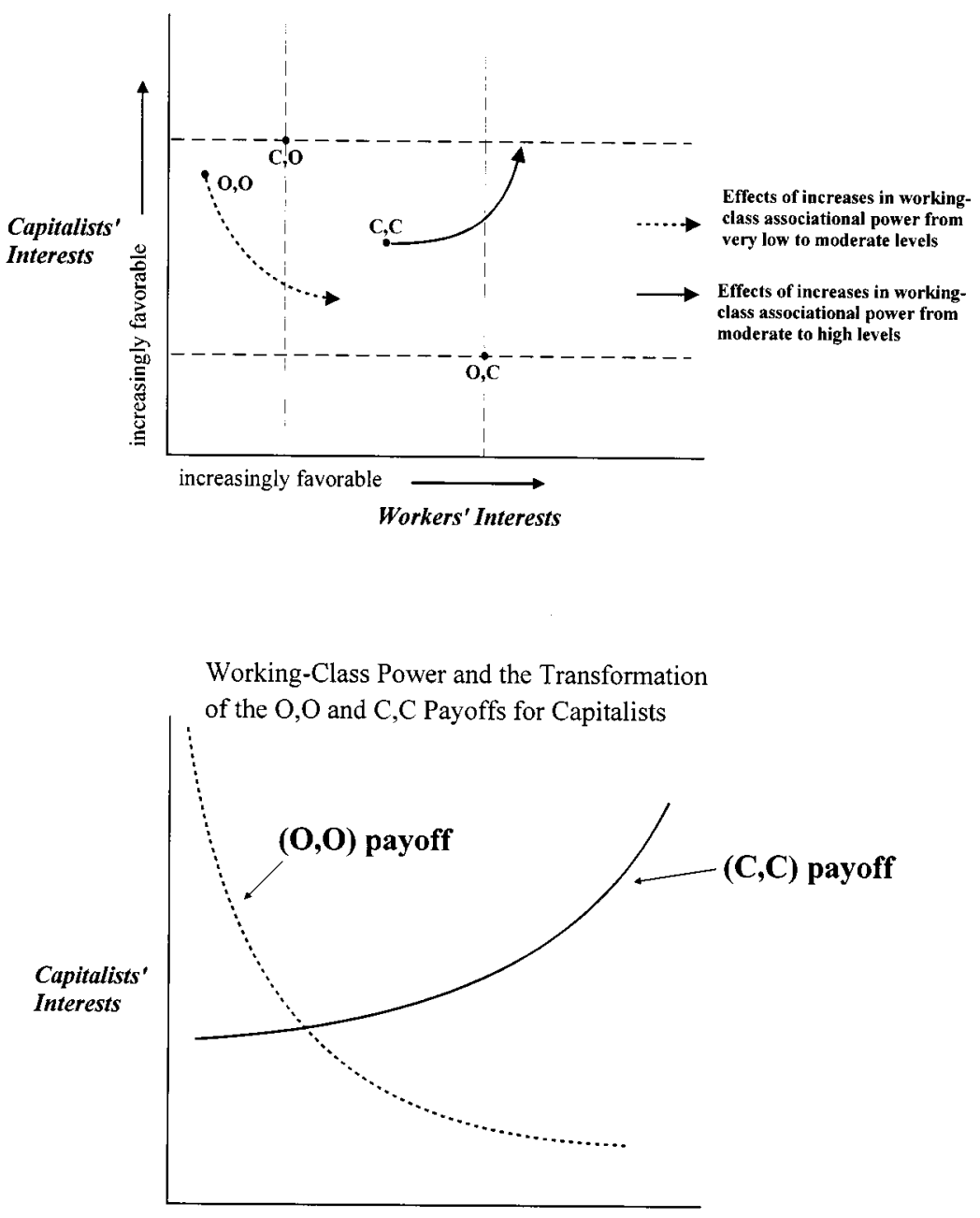

Working-Class Associational Power

FIG. 6.-Working-class power and the transformations of the strategic context of class compromise. 
rium, not because mutual cooperation is the best of all possible payoffs for capitalists. ${ }^{16}$ The two curves in figure 6 are both nonlinear: one, $(\mathrm{O}, \mathrm{O})$, downward sloping and the other, $(\mathrm{C}, \mathrm{C})$, upward sloping. The nonlinear shape of these relations is important for the proposed reverse-J model of class compromise, since if these two curves were each linear, they would generate a linear overall relation between workers' power and capitalists' interests. The shape of the downward sloping $(\mathrm{O}, \mathrm{O})$ curve occurs because relatively modest levels of workers' power can create considerable damage to capitalists' interests but are insufficient to generate much sustainable gain for workers. Increases in workers' power from negligible to moderate, therefore, increase the punishment capacity of workers considerably. Beyond a certain point, however, there are diminishing returns in the additional degree of harm to capitalists generated by additional working-class strength. Once workers are sufficiently strong to prevent capitalists from arbitrarily firing workers, for example, being even stronger does not yield additional gains in job security. The $(\mathrm{C}, \mathrm{C})$ curve is nonlinear and upward sloping because the positive gains capitalists can realize by virtue of workers' power only occur when workers are sufficiently well organized and solidaristic that their associations can effectively sanction defectors from cooperation both among their own members and among capitalists. Until worker associations are at least moderately powerful, they lack this dual-disciplining capacity and thus generate little positive effect on capitalists' interests.

This, then, is the central game-theoretic logic underlying the argument developed in this article: as working-class power increases, the unilateral capitalist domination game is initially shifted to a pure conflict game, making negative class compromise possible; with further increases in working-class associational strength, the strategic environment can shift toward an iterated prisoner's dilemma, opening the prospect for positive class compromise. The more the game shifts toward an assurance gameeven though it is unlikely to actually become one-the more stable the possibility of positive class compromise will become. Underlying this double shift is thus the problem of the relation of working-class associational power to the interests of capitalists, to which we now turn.

${ }^{16}$ It is difficult to find direct empirical evidence that the shape of the curve is a reverseJ, i.e., that capitalists are best off in the $(\mathrm{C}, \mathrm{O})$ equilibrium of the unilateral capitalist domination game. The observation that in countries with relatively disorganized working classes, such as the United States, the capitalist class and CEOs are personally much richer than in countries with highly organized working classes is consistent with the reverse-J argument, but it is potentially confounded by many other factors. 


\section{A CURVILINEAR MODEL OF POSITIVE CLASS COMPROMISE}

To the extent that increases in working-class power can contribute not merely to the realization of working-class material interests, but also to the realization of some capitalist-class interests, class compromises are likely to be more stable and beneficial for workers. To the extent that every increase in working-class power poses an increasing threat to capitalist-class interests, capitalists' resistance is likely to be more intense, and class compromises, even if achieved, are likely to be less stable. The intensity of class struggle, therefore, is not simply a function of the relative balance of power of different classes, but also of the intensity of the threat posed to dominant interests by subordinate-class power.

If the relationship between workers' power and capitalists' interests were the simple inverse relationship of figure 1, then class compromises would always be relatively fragile and vulnerable to attack, for capitalists' interests would always be served by taking advantage of opportunities to undermine workers' power. Negative class compromise would be the most one could achieve. If the shape of the relationship is as pictured in figure 2 , on the other hand, then class compromise can potentially become a relatively durable feature of a set of institutional arrangements. In general, when class conflict is located in the upward-sloping region of this curve, class compromises are likely to be both more stable and more favorable for the working class. If the shape of this curve assumes the form of a more U-shaped version of a reverse-J (i.e., if the upward-sloping section becomes more symmetrical), then conditions for class compromise can be said to be more favorable; if the reverse-J degenerates into a strictly downward-sloping curve, then the conditions for class compromise become less favorable.

In order to more deeply understand the social processes reflected in the reverse-J hypothesis of figure 2, we need to elaborate and extend the model in various ways. First, we will examine more closely the underlying causal mechanisms that generate this curve. Second, we will extend the range of the figure by examining what happens at extreme values of workingclass associational power. Finally, we will examine various ways in which the institutional environment of class conflict determines which regions of this curve are historically accessible as strategic objectives.

\section{Mechanisms Underlying the Reverse-J Relation}

The reverse-J curve presented in figure 2 can be understood as the outcome of two kinds of causal processes-one in which the interests of capitalists are increasingly undermined as the power of workers increases and a second in which the interests of capitalists are enhanced by the increas- 

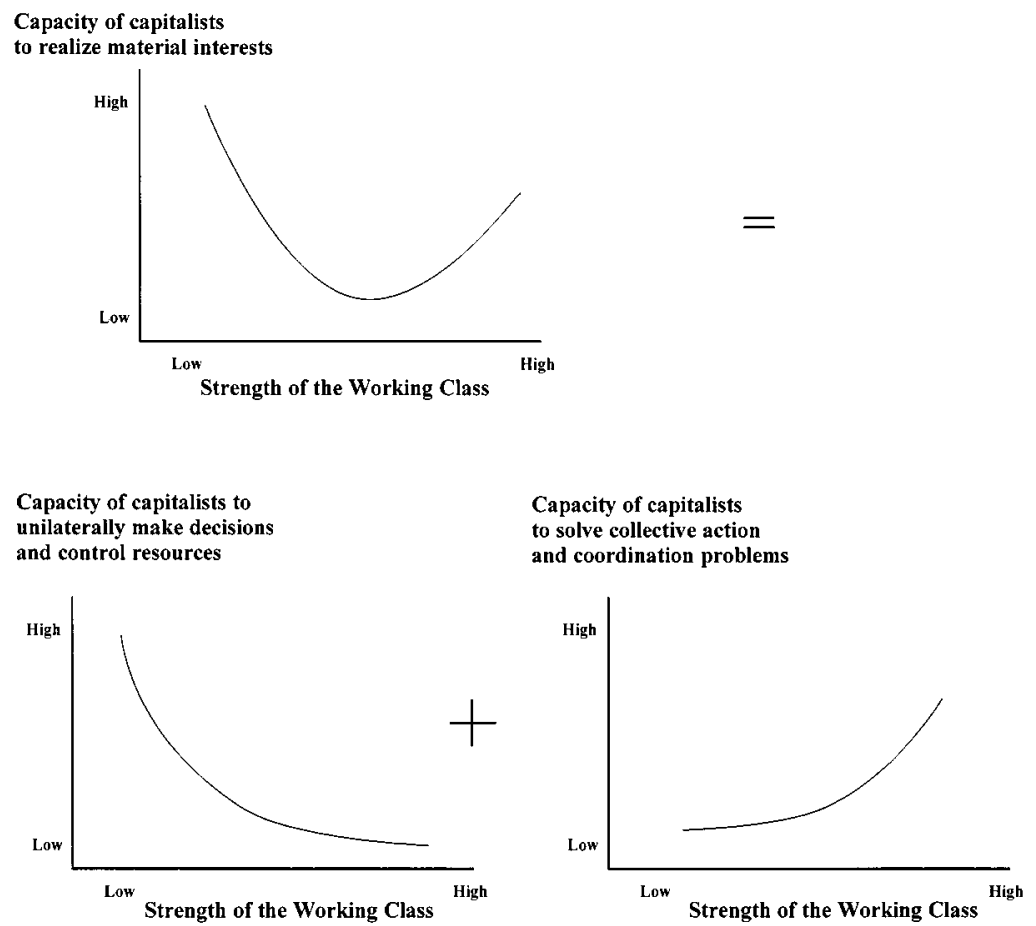

FIG. 7.-Decomposition of the relationship between interests of capitalists and associational strength of workers.

ing power of workers. These are illustrated in figure 7. In broad terms, the downward-sloping curve reflects the ways in which increasing power of workers undermines the capacity of capitalists to unilaterally make decisions and control resources of various sorts, while the upward-sloping curve reflects ways in which the associational power of workers may help capitalists solve certain kinds of collective action and coordination problems. The specific nonlinear shapes of these curves are derived from the shapes of the curves in figure 6.

The mechanisms that generate the component curves in figure 7 can be differentiated across the three institutional spheres within which class compromises are forged: exchange, production, and politics. These mechanisms are summarized in figure 8.

The sphere of exchange. - Capitalists have a range of material interests within the sphere of exchange that bear on their relationship with the working class: minimizing labor costs, having an unfettered capacity to hire and fire without interference, selling all of the commodities they pro- 


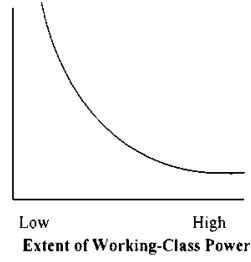

\begin{tabular}{l|lll|}
\multicolumn{1}{c}{$\begin{array}{l}\text { Characteristic } \\
\text { forms of working- } \\
\text { class power }\end{array}$} & $\begin{array}{l}\text { Capitalist-class interests } \\
\text { threatened by increasing } \\
\text { working-class power }\end{array}$ & $\begin{array}{l}\text { Capitalist-class interests } \\
\text { facilitated by increasing } \\
\text { working-class power }\end{array}$ \\
\cline { 2 - 4 } $\begin{array}{l}\text { Sphere of } \\
\text { politics }\end{array}$ & Political Parties & $\begin{array}{l}\text { Unilateral political influence } \\
\text { over redistributive policies }\end{array}$ & $\begin{array}{l}\text { Ability to sustain stable tripartite } \\
\text { corporatist cooperation }\end{array}$ \\
$\begin{array}{l}\text { Sphere of } \\
\text { exchange }\end{array}$ & Trade Unions & $\begin{array}{l}\text { Unilateral ability to hire, } \\
\text { fire, and make wage offers }\end{array}$ & $\begin{array}{l}\text { Ability to restrain wages in tight } \\
\text { labor markets; ability to sell what } \\
\text { is produced (Keynesian effects) }\end{array}$ \\
$\begin{array}{l}\text { Sphere of } \\
\text { production }\end{array}$ & Works Councils & $\begin{array}{l}\text { Unilateral ability to control } \\
\text { labor process and job } \\
\text { structure }\end{array}$ & $\begin{array}{l}\text { Ability to elicit complex forms of } \\
\text { vertical and horizontal cooperation; } \\
\text { cheaper solution to information } \\
\text { problems in production }\end{array}$ \\
& & &
\end{tabular}

FIG. 8.-Decomposition of the relationship between working-class power and capitalist-class interests in the sphere of politics, exchange, and production.

duce, and having a labor force with a particular mix of skills in a labor market that provides predictable and adequate supplies of labor. As has often been argued by both Marxists and non-Marxist political economists, some of these interests contradict each other. Most notably, the interest of capitalists in selling commodities means that it is desirable for workersas-consumers to have a lot of disposable income, whereas capitalists' interest in minimizing their own wage bill implies an interest in paying workers-as-employees as little as possible.

Increases in working-class associational power generally undermine the capacity of individual capitalists to unilaterally make decisions and allocate resources within labor markets. In the absence of unions, capitalists can hire and fire at will and set wages at whatever level they feel is most profitable. Of course, this does not mean that employers set wages without any constraints whatsoever. Their wage offers will be constrained by the tightness or looseness of the labor market, the reservation wages of workers, and, as discussed earlier, the need to pay workers a sufficiently high wage to motivate individual workers to work diligently. Capitalists' decisions are thus always constrained by the actions of individual workers and by general economic conditions. The issue here, however, is the extent of constraint on capitalists imposed by the collective action of workers 
reflecting their associational power in various forms. Such associational power reduces capitalists' individual capacity to make profit-maximizing decisions on labor markets and thus hurts their material interests.

If capitalists' interests within the sphere of exchange consisted entirely of interests in their individual ability to buy and sell with minimal constraint, then something close to the inverse relation portrayed in figure 1 would probably hold. But this is not the case. The material interests of capitalists - their ability to sustain a high and stable rate of profit-depends upon the provision of various aggregate conditions within the sphere of exchange, and these require coordination and collective action. The solution to at least some of these coordination problems can be facilitated by relatively high levels of working-class associational power. ${ }^{17}$

The classic example of this is the problem of inadequate aggregate demand for the consumer goods produced by capitalists. This is the traditional Keynesian problem of how raising wages and social spending can underwrite higher levels of aggregate demand and thus help solve "underconsumption" problems in the economy. Inadequate consumer demand represents a collective action problem for capitalists: capitalists simultaneously want to pay their own employees the lowest wages possible and want other capitalists to pay the highest wages possible in order to generate adequate consumer demand for products. High levels of unionization, in effect, prevent individual firms from "defecting" from the cooperative solution to this dilemma. Working-class strength can also contribute to more predictable and stable labor markets. Under conditions of tight labor markets, where competition for labor among capitalists would normally push wages up, perhaps at rates higher than the rate of increase of productivity, thus stimulating inflation, high levels of working-class associational power can also contribute to wage restraint (see Calmfors and Driffill 1988; Glynn 1995; Pontusson 1997). Wage restraint is an especially complex collective action problem: individual capitalists need to be prevented from defecting from the wage-restraint agreement (i.e., they must be prevented from bidding up wages to workers in an effort to lure workers away from other employers given the unavailability of workers in the labor market), and individual workers (and unions) need to be prevented from defecting from the agreement by trying to maximize wages under tight labor market conditions. Wage restraint in tight labor markets,

${ }^{17}$ This does not mean that working-class associational power is a necessary condition for the solution to such coordination problems. There may be other devices that may constitute alternative strategies for accomplishing this. All that is being claimed is that working-class associational power can constitute a mechanism that makes it easier to solve such problems. 
which is important for longer term growth and contained inflation, is generally easier where the working class is very well organized, particularly in centralized unions, than where it is not.

These positive effects of workers' strength on capitalists' interests in the sphere of exchange need not imply that capitalists themselves are equally well organized in strong employers associations, although as the history of Northern European neocorporatism suggests, strongly organized working-class movements tend to stimulate the development of complementary organization on the part of employers. In any case, the ability of workers' power to constructively help solve macroeconomic problems is enhanced when capitalists are also organized.

Assuming that the positive Keynesian and labor market effects of working-class power are generally weaker than the negative wage cost and firing discretion effects, the combination of these processes yields the reverse-J relationship for the sphere of exchange in figure 8 .

The sphere of production. - A similar contradictory quality of the interests of capitalists with respect to workers occurs within the sphere of production: on the one hand, capitalists have interests in being able to unilaterally control the labor process (choosing and changing technology, assigning labor to different tasks, changing the pace of work, etc.), and on the other hand, they have interests in being able to reliably elicit cooperation, initiative, and responsibility from employees.

As working-class associational power within production increases, capitalists' unilateral control over the labor process declines. This does not mean that capitalists are necessarily faced with rigid, unalterable work rules, job classifications, and the like, but it does mean that changes in the labor process need to be negotiated and bargained with representatives of workers rather than unilaterally imposed. Particularly in conditions of rapid technical change, this may hurt capitalists' interests.

On the other hand, at least under certain social and technical conditions of production, working-class associational strength within production may enhance the possibilities for more complex and stable forms of cooperation between labor and management. To the extent that working-class strength increases job security and reduces arbitrariness in managerial treatment of workers, the workers' time horizons for their jobs are likely to increase and along with this their sense that their future prospects are linked to the welfare of the firm. This in turn may contribute to a sense of loyalty and greater willingness to cooperate in various ways.

The German case of strong workplace-based worker organization built around works councils and codetermination is perhaps the best example. Streeck describes how codetermination and works councils positively help capitalists solve certain problems: 
What, then, is specific about codetermination? Unlike the other factors that have limited the variability of employment, codetermination has not merely posed a problem for enterprises, but has also offered a solution. While on the one hand codetermination has contributed to growing organizational rigidities, on the other hand, and at the same time, it has provided the organizational instruments to cope with such rigidities without major losses in efficiency. ... The works councils not only shares in what used to be managerial prerogatives, but also accepts responsibility for the implementation and enforcement of decisions made under its participation. This constellation has frequently been described as "integration" or "cooptation" of labor or organized labor, in management; with the same justification, however it can be seen as "colonization" of management, and in particularly manpower management, by the representatives of the workforce. The most adequate metaphor would probably be that of a mutual incorporation of capital and labor by which labor internalizes the interests of capital just as capital internalizes those of labor, with the result that works council and management become subsystems of an integrated, internally differentiated system of industrial government which increasingly supersedes the traditional pluralistadversarial system of industrial relations. (Streeck 1992, pp. 160, 164; emphasis in the original)

This tighter coupling of interests of labor and capital with the resulting heightened forms of interclass cooperation helps employers solve a range of concrete coordination problems in workplaces: more efficient information flows within production (since workers have more access to managerial information and have less incentive to withhold information as part of a job-protection strategy); more efficient adjustments of the labor process in periods of rapid technological change (since workers are involved in the decision making and are thus less worried that technological change will cost them their jobs, they are more likely to actively cooperate with the introduction of new technologies); and more effective strategies of skill formation (since workers, with the most intimate knowledge of skill bottlenecks and requirements, are involved in designing training programs). Most broadly, strong workplace associational power of workers creates the possibility of more effective involvement of workers in various forms of creative problem solving. ${ }^{18}$

With so many positive advantages of such cooperative institutions, it might seem surprising that strong workplace associational power is so rare

\footnotetext{
${ }^{18}$ It is possible, under certain social and cultural conditions, for some of these forms of cooperation to emerge and be sustained without strong workplace associational power of workers. This is often the way the relatively cooperative system of employment relations in Japan is described (see, e.g., Nakane 1970), although others have criticized such culturalist views (e.g., Aoki 1988, pp. 304-13). In any event, under many conditions high levels of worker cooperation within production are likely to be difficult to sustain if they are not backed by some form of significant associational power.
} 
in developed capitalist countries. The reason, as I have argued throughout this article, is that such cooperative advantages come at a cost to capital. Streeck recognizes this even in the German case: "Above all, codetermination carries with it considerable costs in managerial discretion and managerial prerogatives. . . Integration cuts both ways, and if it is to be effective with regards to labor it must bind capital as well. This is why codetermination, for all its advantages, is seen by capital as a thoroughly mixed blessing. ... Both the short-term economic costs and the long-term costs in authority and status make the advantages of codetermination expensive for the capitalist class, and thus explains the otherwise incomprehensible resistance of business to any extension of codetermination rights" (Streeck 1992, p. 165).

Because of these costs, capitalists in general will prefer a system of production in which they do not have to contend with strong associational power of workers in production. Thus, the reverse-J shape of the functional relation between workers' power and capitalists' interests within production is formed.

The sphere of politics. - The two components of the reverse-J relationship between working-class associational power and capitalists' interests are perhaps most obvious in the sphere of politics. As a great deal of comparative historical research has indicated, as working-class political power increases, the capitalist state tends to become more redistributive: the social wage increases and thus the reservation wage of workers is higher; taxation and transfer policies reduce income inequality; and in various ways, labor power is partially decommodified. All of these policies have negative effects on the material interests of high-income people in general and capitalists in particular. Working-class political power also tends to underwrite institutional arrangements that increase working-class power within the sphere of exchange and often within the sphere of production as well. Working-class associational power in the political sphere, therefore, may also contribute to the downward-sloping curves in the spheres of exchange and production.

The upward-sloping class compromise curve in the sphere of politics is the central preoccupation of social democracy. The large literature on tripartite state-centered corporatism is, in effect, a literature on how the interests of capitalists can flourish in the context of a highly organized working class (Esping-Andersen 1990; Schmitter and Lembruch 1979; Schmitter 1988). Sweden, until the mid-1980s, is usually taken as the paradigm case: the social-democratic party's control of the Swedish state facilitated a set of corporatist arrangements between centralized trade unions and centralized employers' associations that made possible a long, stable period of cooperation and growth. The organizational links between the labor movement and the social-democratic party were critical for this sta- 
bility, since it added legitimacy to the deals that were struck and increased the confidence of workers that the terms of the agreement would be upheld in the future. This made it possible over a long period of time for Swedish capitalism to sustain high capacity utilization, very low levels of unemployment, and relatively high productivity growth. State-mediated corporatism anchored in working-class associational strength in the political sphere played a significant role in these outcomes.

The inventory of mechanisms in figure 8 provides a preliminary set of variables for characterizing the conditions of class compromise within different units of analysis across time and space. Class compromises within the sphere of exchange can occur in local, regional, or national labor markets, or within labor markets linked to particular sectors. Production-level compromises typically occur within firms, but they may also be organized within sectors..$^{19}$ Class compromises in the sphere of politics are especially important within the nation state, but local and regional political class compromises are also possible. The emergence of various forms of mesocorporatism involving local and regional levels of government may indicate the development of political class compromises within subnational units. The reverse-J curves that map the terrain of class compromise, therefore, can be relevant to the analysis of class compromises in any unit of analysis, not simply entire countries.

Different countries, then, will be characterized by different combinations of values on these three pairs of class compromise curves. ${ }^{20}$ In Ger-

\footnotetext{
${ }^{19}$ In the spheres of production and exchange, there may be considerable heterogeneity in the shape of the class compromise curves and the degree of working-class associational power across firms and sectors. The result is that within a given country the conditions for class compromise may be much more favorable in some firms and sectors than in others. Within the sphere of production, it is easy enough to see how the upward-sloping curve can be restricted to a particular sector or even firm, since most of the gains from cooperation are contained within firms. In the sphere of exchange, while many of the positive effects of high levels of unionization for capitalists come from aggregate, macroeconomic effects, some of the positive effects-such as stabilization of labor markets, rationalized skill formation, and wage restraint in tight labor markets-may be concentrated in specific sectors or localities. The reverse-J curve characterizing a given sphere, therefore, is itself an amalgamation of the distribution of such curves across firms, sectors, and other less-aggregated units of analysis.

${ }^{20}$ The actual variation across time and place is, of course, much more complicated than is being portrayed here. Countries will vary not simply in where they are located on each of these curves, but also on: (1) the relative weights of the various curves in defining the overall configuration for the society; (2) the units of analysis within countries within which class compromises are most rooted; and (3) the specific shapes of the component curves themselves. In some times and places, for example, the upwardsloping segments of some of the curves might be relatively flat, and in other cases, quite steep. My theoretical understanding of these relations is insufficient to say anything very systematic about these sources of variation.
} 


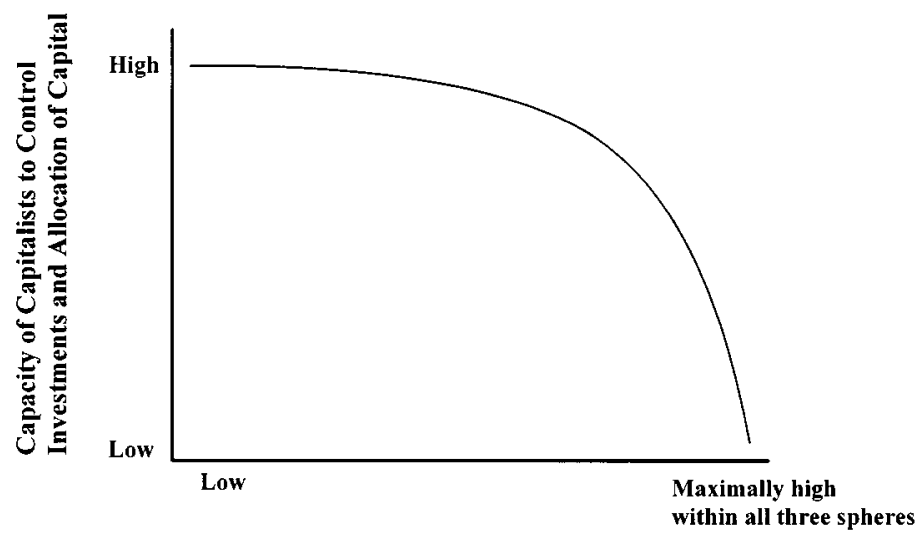

Associational Power of the Working Class

FIG. 9.- Interests of capital and power of workers with respect to the control over investments.

many, for example, working-class associational power is especially strong within the sphere of production, somewhat less strong in the sphere of exchange, and rather weaker in the sphere of politics. In Sweden-at least in the heyday of social democracy - it has been very strong in the spheres of exchange and politics and perhaps a bit weaker in the sphere of production. In the United States, working-class associational power has dwindled within all three spheres but is strongest in the sphere of exchange within certain limited sectors. The overall reverse-J curve for class compromise within a society, therefore, is the result of a complex amalgamation of the component curves within each of these spheres.

Making the Model More Complex: Extending the Theoretical Domain of Variation

The range of variation in figures 2 and 8 can be considered the typical spectrum of possibilities in contemporary, developed capitalist societies. It will be helpful for our subsequent analysis to consider what happens when working-class power increases toward the limiting case of societywide, working-class organization and solidarity simultaneously in all three spheres of class compromise. This corresponds to what might be termed "democratic socialism," where socialism is not defined as centralized state ownership of the means of production but as working-class collective control over capital.

What happens to capitalist-class interests as working-class associational power approaches this theoretical maximum? Figure 9 presents the rela- 
tionship between one crucial aspect of capitalists' interests-their control over investments and accumulation (allocation of capital) - and workingclass power. The control over investments is perhaps the most fundamental dimension of "private" ownership of the means of production within capitalism. In most capitalist societies, even as working-class power increases, this particular power of capital is not seriously eroded. Even with strong unions and social-democratic parties, capitalists still have the broad power to disinvest, to choose their individual rate of savings, to turn their profits into consumption or allocate them to new investments, and so on. Of course, all capitalist states have capacities to create incentives and disincentives for particular allocations of capital (through taxes, subsidies, tariffs, etc.). And in special circumstances, "disincentives" can have a significant coercive character, effectively constraining capitalists' capacity to allocate capital. Still, this fundamental aspect of capitalists' property rights is not generally threatened within the normal range of variation of working-class power. When working-class associational power approaches its theoretical maximum, however, the right of capitalists to control the allocation of capital is called into question. Indeed, this is the heart of the definition of democratic socialism - popular, democratic control over the allocation of capital. This suggests the shape of the curve in figure 9: a relatively weak negative effect of working-class power on capitalists' interests with respect to the control over the basic allocation of capital until working-class power reaches a very high level, at which point those interests become seriously threatened. ${ }^{21}$

When figure 9 is added to figure 2, we get the roller-coaster curve in figure 10. There are two maxima in this theoretical model: the capitalist utopia, in which the working class is sufficiently atomized and disorganized to give capitalists a free hand in organizing production and appropriating the gains from increased productivity without fear of much collective resistance; and the social-democratic utopia, in which working-class associational power is sufficiently strong to generate high levels of corporatist cooperation between labor and capital without being so strong as

\footnotetext{
${ }^{21}$ The $\mathrm{x}$-axis in fig. 9 is working-class associational power undifferentiated into the spheres of production, exchange, and politics. It thus represents an undertheorized amalgam of the associational power within the three spheres (which are themselves amalgams of associational power across the various units of analysis that make up a sphere). The underlying intuition is that viable democratic socialism requires high levels of workers' associational power within all three spheres and that a sustainable threat to fundamental capitalists' property rights under democratic conditions can only occur when such unified associational power occurs. This does not imply, however, that the three spheres are of equal weight in this theoretical gestalt. Traditionally, Marxists have argued that working-class power at the level of the state is most decisive for challenging capitalist property rights, whereas syndicalists have argued that the pivot is workers' power within production.
} 


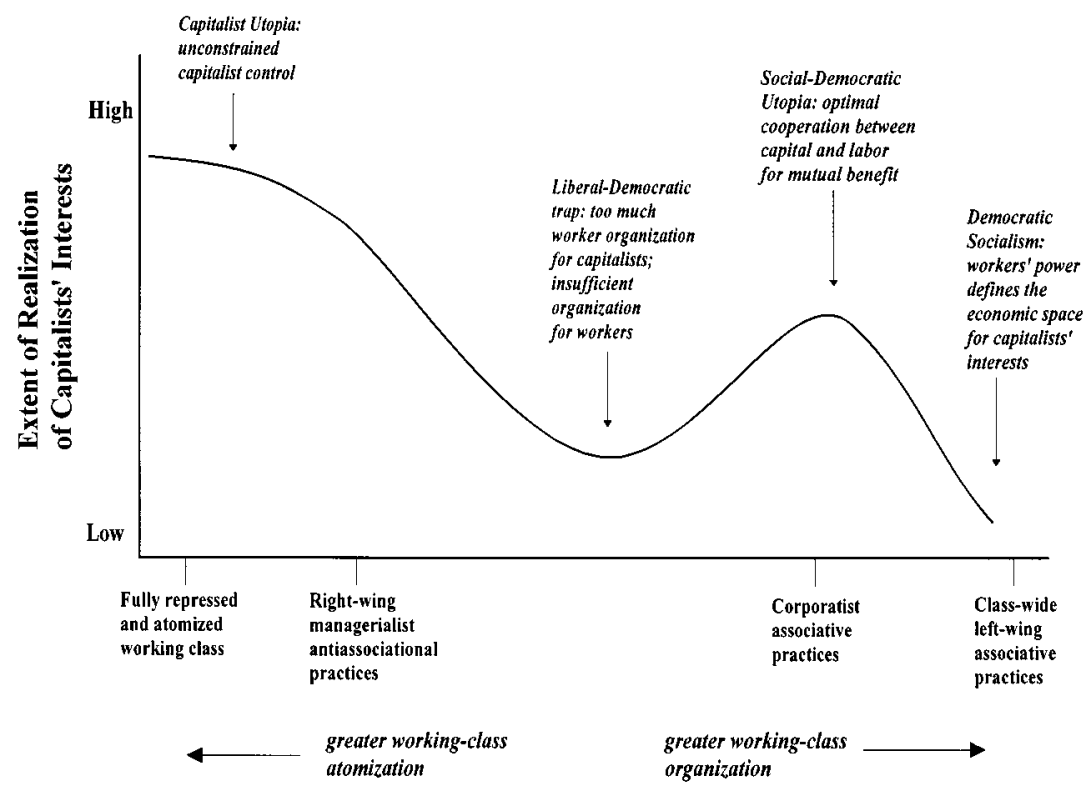

Degree of Associational Power in Economic Organization and Politics

FIG. 10.-Expanded model of working-class associational power and capitalists' interests.

to threaten basic capitalist property rights. These two maxima, however, constitute quite different strategic environments for workers and capitalists. Statically, capitalists should only care about where they sit on the vertical axis of this figure: if you draw a horizontal line through the figure that intersects the curve at three places, capitalists should be statically indifferent among these three possibilities. Understood dynamically, however, capitalists in general will prefer points in the left-hand region of the curve.

It is at least in part because of this threat of a society-wide shift in the balance of class power that capitalists might prefer for working-class associational power to remain to the left of the social-democratic "peak" of this curve, even though this peak might be theoretically advantageous to capitalists' interests. Arriving at the peak looks too much like a Trojan Horse: small additional changes in associational power could precipitate a decisive challenge to capitalists' interests and power. The local maximum of the "social-democratic utopia" in figure 10 may thus be a kind of tipping point, which is seen by capitalists as too risky a zone to inhabit. This is one interpretation of the strident opposition by Swedish capitalists 
to the initial formulation of the "wage-earners fund" proposal in Sweden in the 1970s. The wage-earners fund, as initially conceived, was a proposal through which Swedish unions would gain increasing control over the Swedish economy via the use of union pension funds to purchase controlling interests in Swedish firms. From the point of view of economic performance and even the middle-run profit interests of Swedish firms, it was arguable that this might be beneficial for Swedish capital, but it raised the possibility of a long-term slide toward democratic socialism by significantly enhancing the power of Swedish labor. The result was a militant attack by Swedish capitalists against the social-democratic party. As Glynn (1995, pp. 53-54) writes: "The policies which the Social Democrats were proposing impinged on the authority and freedom of action of business which was supposed to be guaranteed in return for full employment and the welfare state. This seems to lie at the root of the employers repudiation of the Swedish model, of which full employment was a central part."

The different regions of this curve correspond to the different gametheory models in figure 5. The capitalists' utopia corresponds to the unilateral capitalist domination game in which $(\mathrm{C}, \mathrm{O})$ is the equilibrium solution. The downward-sloping region in the center of the figure is the pure conflict game where, at best, negative class compromise is possible. The upward-sloping part of the curve is the iterated prisoner's dilemma, where a stable (C,C) solution, a positive class compromise, can emerge. The apex of this region of the curve, the social-democratic utopia, is the point that is closest to an assurance game. If in fact it actually became a proper assurance game (i.e., the $[\mathrm{C}, \mathrm{C}]$ payoff in figure 5 moved into the northeast quadrant of the payoff matrix), then the central region of the curve in figure 10 would become a J-curve rather than a reverse-J; the social-democratic utopia would be higher than the capitalist utopia and become a kind of social-democratic nirvana in which mutual cooperation between classes was self-reinforcing, no longer resting on a background condition of potential working-class opposition. Finally, democratic socialism corresponds to the unilateral working-class domination game in which $(\mathrm{O}, \mathrm{C})$ is the equilibrium solution.

\section{Working-Class Interests and the Class Compromise Curve}

The models in figure 5 contain both working-class interests and capitalistclass interests. Figure 11 adds working-class interests to the class compromise curve in figure 10. The different regions of these curves can be thought of as specific hypotheses about the effects of marginal changes of working-class power on the relationship between workers' interests and capitalists' interests: 


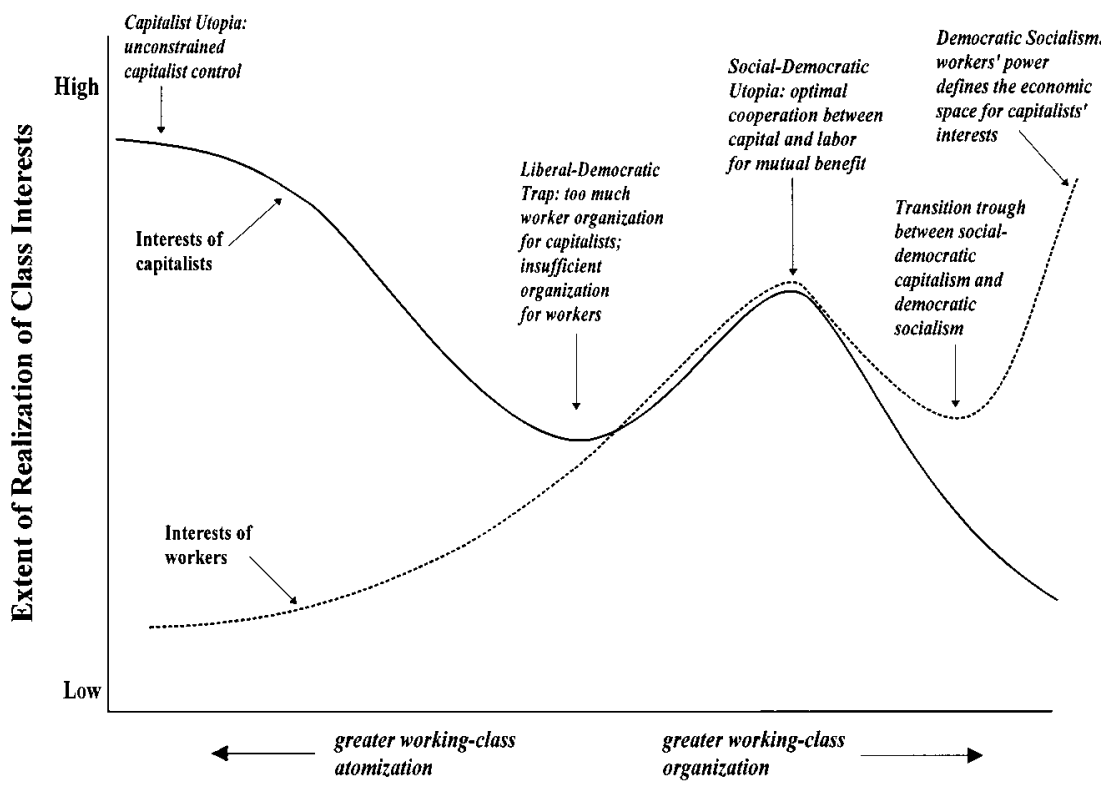

Degree of Associational Power in Economic Organization and Politics

FIG. 11.-Working-class associational power, working-class interests, and capitalists' interests.

1. The gap between workers' interests and capitalists' interests is greatest at the ends of the spectrum: when working-class associational power is weakest (the fully atomized working class) or at the maximum strength (democratic socialism).

2. Increases in working-class associational power steadily increase the realization of working-class material interests up to relatively high levels of associational power. Of course, in actual historical processes of increasing working-class power, it may well happen that there will be episodes in which the resistance of capitalists results in declines in the realization of working-class interests. Nevertheless, in general, increasing workers' power is expected to improve the realization of working-class interests.

3. The region of the curve around the "liberal-democratic trap" is the region corresponding to the shift from the mutual opposition $(\mathrm{O}, \mathrm{O})$ payoff in models 2 to the prisoner's dilemma in model 3, figure 5: workers effectively oppose capitalists' interests and capitalists effectively oppose workers' interests. 
4. There is one region of the curve where the functional relation between workers' power and class interests has the same general shape for both workers and capitalists: the upward-sloping section to the right of the liberal-democratic trough. This is the region of maximally stable positive class compromise.

5. As working-class power extends beyond corporatist associative practices, the immediate realization of working-class interests again decline. This region of the curve defines the "transition trough" between capitalism and socialism discussed by Adam Przeworski (1985). Capitalists respond to the threat of losing control over the allocation of capital by disinvesting, shifting investments to other places, or by more organized forms of a "capital strike." This has the effect of provoking an economic decline, which hurts workers' material interests. It is only when workers' associational power increases to the point at which investments can be democratically allocated (in the sense of democratically imposed direction on allocation) that the working-class interest curve once again turns upward. Once there is a full realization of hypothetical democratic socialism, the interests of workers and capitalists are once again maximally divergent.

\section{One More Complexity: Zones of Unattainability}

In the practical world of real capitalist societies, not all values within this theoretically defined range are historically accessible. There are two different kinds of exclusion mechanisms that have the effect of narrowing the range of real possibilities. These can be termed systemic exclusions and institutional exclusions.

Systemic exclusions define parts of the curve that are outside the limits of possibility because of the fundamental structural features of the social system. Specifically, the presence of a constitutionally secure democracy removes the fully repressed and atomized working-class part of the curve from the historical stage, and the presence of legally secure capitalist property rights removes the democratic socialism part of the curve. This does not mean that there are no historical circumstances in which these zones of the curve might become strategically accessible, but to get there would require a fundamental transformation of the underlying social structural principles of the society.

Institutional exclusions refer to various kinds of historically variable institutional arrangements, formed within the limits determined by the systemic exclusions, which make it difficult or impossible to move to specific regions of the curve. For example, restrictive labor law can make it difficult to extend working-class associational power toward the corporat- 


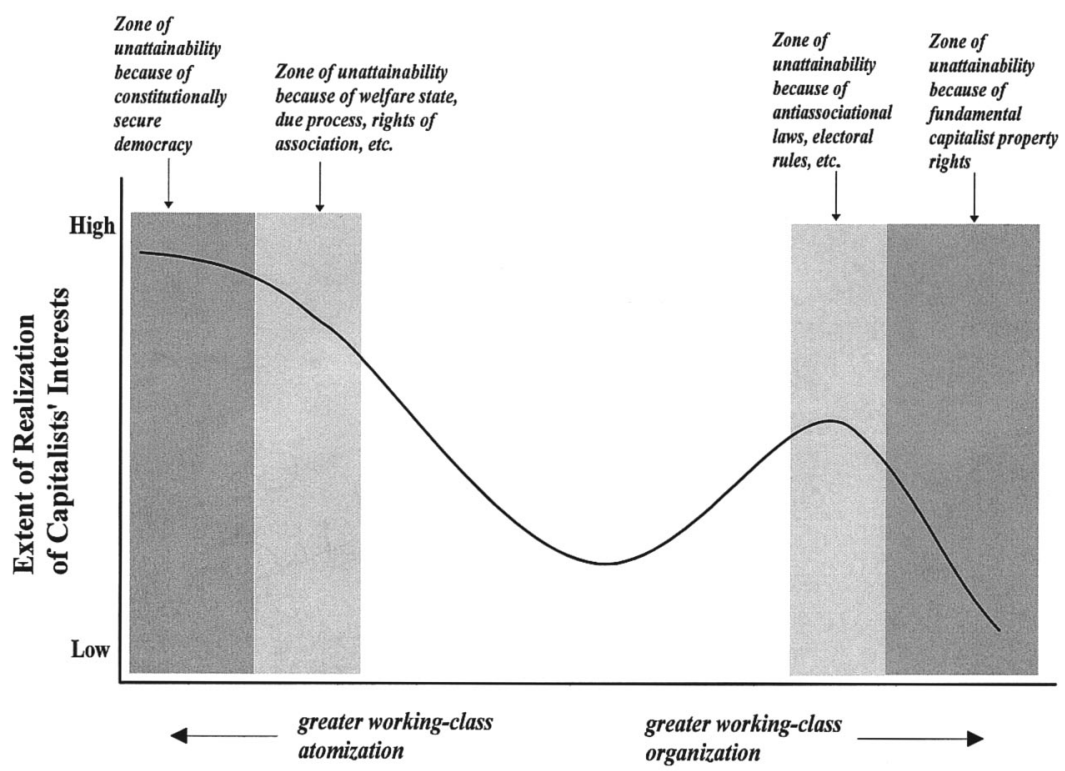

Degree of Associational Power in Economic Organization and Politics

Systemically excluded possibilities
Institutionally excluded possibilities (historically variable)

FIG. 12.-Working-class associational power and capitalists' interests in democratic capitalism.

ist associative practices part of the curve (Rogers 1990). On the other hand, generous welfare state provisions, which render workers less dependent on capital, and strong associational rights, which facilitate unionization, may make it difficult to move toward the right-wing managerialist region. Such institutional exclusions, of course, are themselves the outcomes of historical conflicts and should not be viewed as eternally fixed. But once in place, they help to define the range of feasible strategy immediately open to actors, at least until the time when actors can effectively challenge these institutional exclusions themselves.

These two forms of exclusion are illustrated in figure 12. The central region of the curve defines the space that is immediately accessible strategically. To use a game-theory metaphor adopted by Alford and Friedland (1985), this is the domain of ordinary politics, of liberal versus conservative struggles over "plays" within a well-defined set of institutional "rules of the game." The other regions of the curve become the objects of politics only episodically. Reformist versus reactionary politics are struggles over 
the rules of the game that define institutional exclusions; revolutionary versus counterrevolutionary politics are struggles over the systemic constraints that define what game is being played.

In figure 12, the zones of unattainability defined by the systemic and institutional exclusions symmetrically span the tails of the theoretical curve of possibilities. There is no reason, of course, to believe that the real world is this neat. Indeed, one of the reasons for introducing this complexity is precisely to provide tools for understanding forms of variation across time and place in these exclusions. This historical variability is illustrated in figure 13, which compares the United States and Sweden in the periods of most stable Swedish social democracy and American liberal democracy.

Systemic exclusions in the United States and Sweden are roughly comparable: both have structurally secure democratic states and capitalist property relations. Where they differ substantially is in the nature of the historically variable institutional exclusions that confront their respective working classes.

In the United States, a variety of institutional rules create a fairly broad band of institutional exclusions to the right of the central trough of the curve. Electoral rules that solidify a two-party system of centrist politics and antiunion rules that create deep impediments to labor organizing all push the boundary of this zone of institutional exclusion to the left (Rogers 1990). On the other hand, such things as the weak welfare state, the very limited job protections afforded workers, and laws that guarantee managerial autonomy all have the effect of narrowing the institutional exclusions centered around right-wing managerialist antiassociational practices. The band of accessible strategy in the United States, therefore, affords very little room to maneuver for labor and keeps working-class associational practices permanently lodged on the downward-sloping segment of the curve to the left of the trough.

Swedish institutional exclusions, particularly during the most stable period of social democracy, all work toward facilitating working-class associational power. Labor law is permissive, making it quite easy to form and expand union membership, and the generous welfare state and job protections significantly reduce the scope of right-wing managerialist strategies. The result has been that the Swedish labor movement has for a long time been located on the upward-sloping section of the curve to the right of the trough.

Actors living within these systems, of course, do not directly see this entire picture. To the extent that the institutional exclusion mechanisms have been securely in place and unchallenged for an extended period of time, they may become entirely invisible, and the parts of the curve that they subsume may become virtually unimaginable. From the vantage 

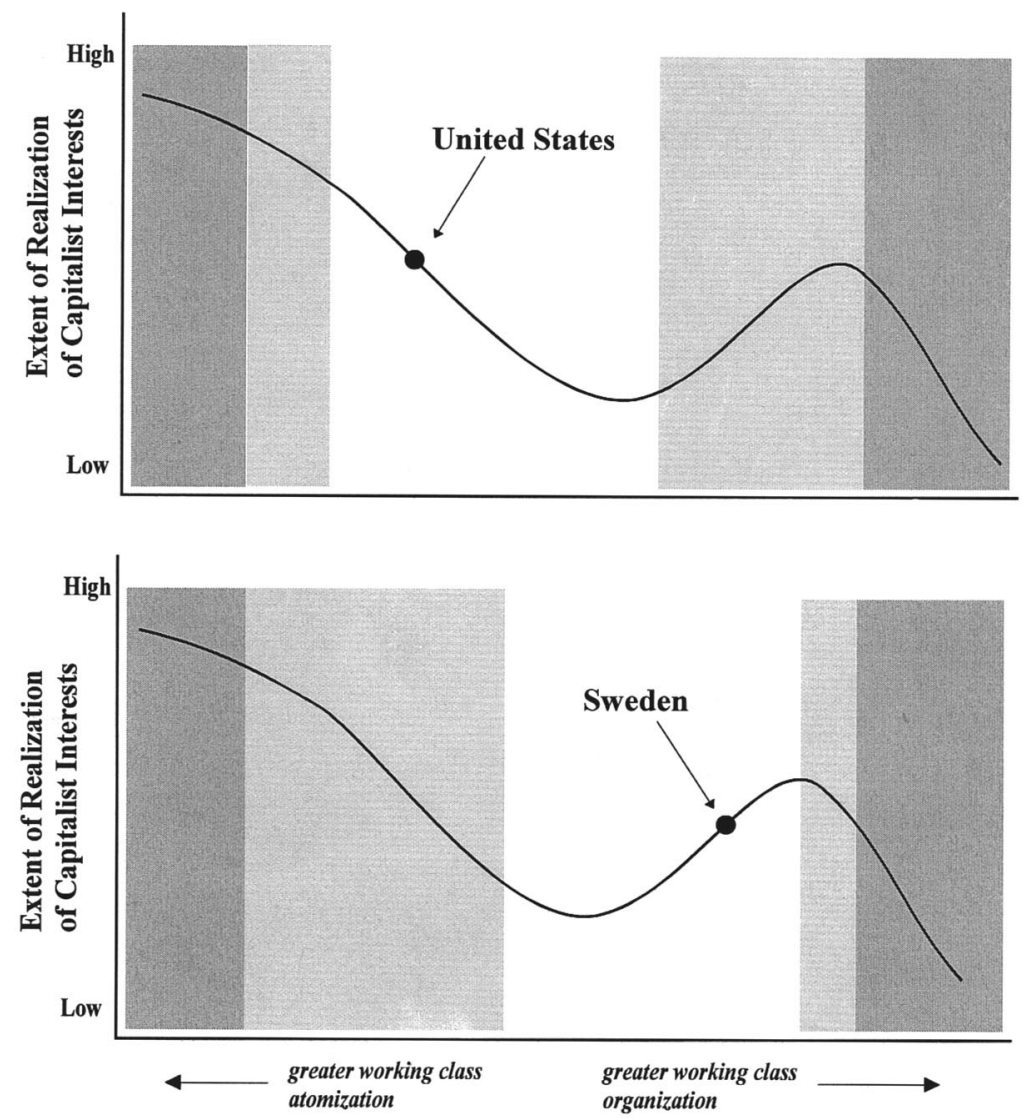

Degree of Associational Power in Economic Organization and Politics

Systemically excluded possibilities
Institutionally excluded possibilities (historically variable)

FIG. 13.-Working-class associational power and capitalists' interests in liberal-democratic capitalism (United States) and social-democratic capitalism (Sweden).

point of actors within the system, therefore, the range of "realistic" possibilities may look like those portrayed in figure 14 rather than figure 13. The American labor movement faces a terrain of possibilities that places it chronically on the defensive. Every marginal increase of workers' strength is experienced by capitalists as against their interests, so when- 

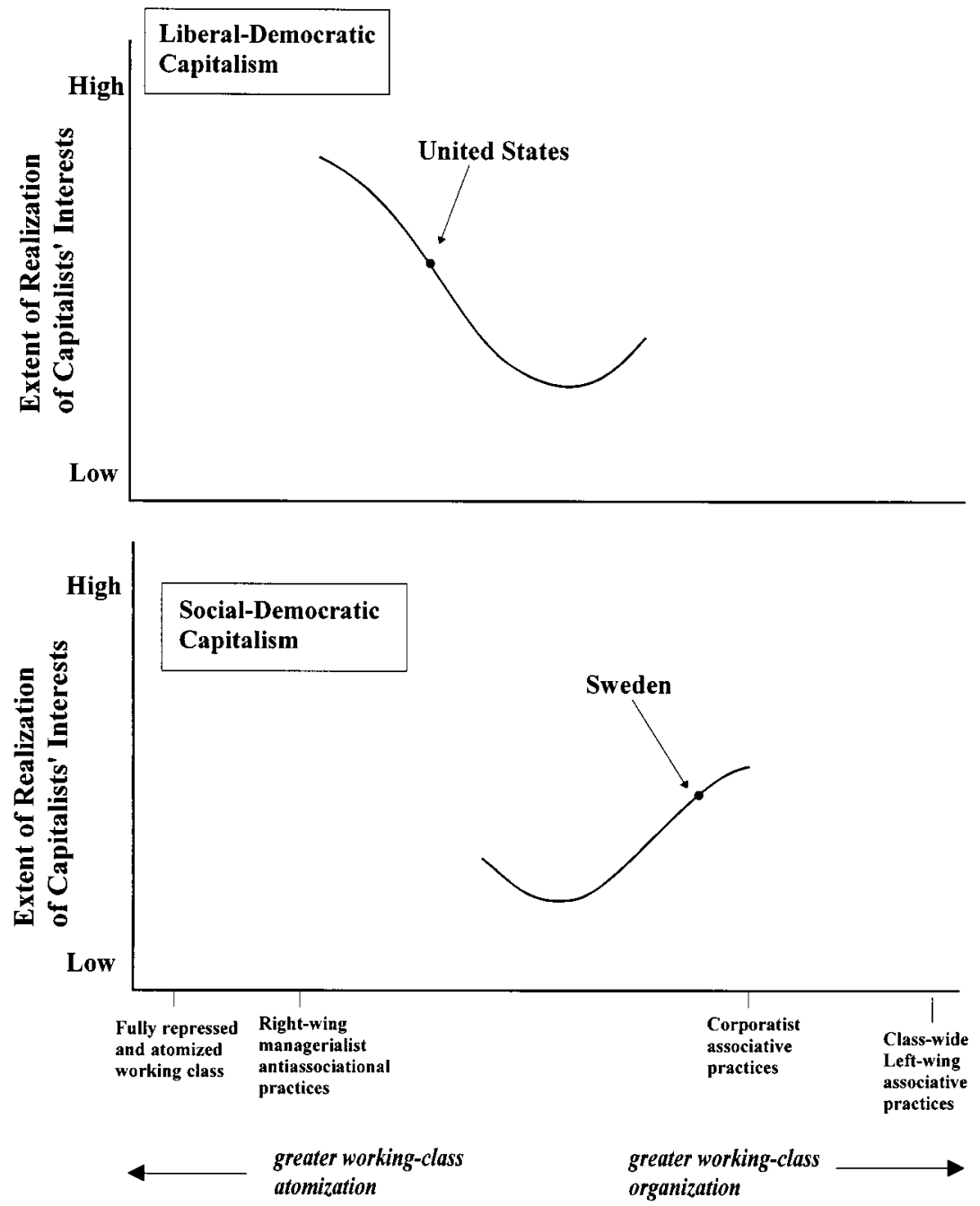

Degree of Associational Power in Economic Organization and Politics

FIG. 14.-Strategic environment for feasible associational politics as seen by the actors in liberal-democratic capitalism and social-democratic capitalism. 
ever the opportunity arises, capitalists attempt to undermine labor's strength. Antiunion campaigns are common, and decertification elections are a regular occurrence. In Sweden, at least until recently, the institutionally delimited strategic environment is much more benign for workers. The central pressure on capitalists has been to forge ways of effectively cooperating with organized labor, of creating institutional spaces in which the entrenched forms of associational power of workers can be harnessed for enhanced productivity. This need not imply that employers actively encourage working-class associational power, but it does suggest less sustained effort to undermine it.

The immediately accessible strategic environments of workers' struggles for associational power, as illustrated in figure 14, should not be viewed as fixed by an unalterable historical trajectory. The range of attainable possibilities can change, both as the result of conscious political projects to change institutional exclusions and as the result of dynamic social and economic forces working "behind the backs" of actors. Institutional exclusions are created by victories and defeats in historically specific struggles; they can potentially be changed in a similar fashion. But equally, dynamic changes within economic structures can potentially change the shape of the curve itself. It is to that issue that I now turn in a more speculative manner.

\section{TRANSFORMATIONS OF THE TERRAIN OF CLASS COMPROMISE}

If the general model of class compromise we have been exploring is reasonably on target, then this suggests that the prospects of positive class compromise can be altered through three different routes: (1) by changes in the basic shape of the curve; (2) by changes in the institutional rules of the game, which determine the range of institutional exclusions; and (3) by changes in the associational power of workers within the strategically accessible range of possibilities.

The first of these involves the functional relations depicted in figures 7 and 8, the second involves the institutional zones of unattainability in figure 12 , and the third concerns the specific location within a strategic space as in figure 14. A full-blown theory of class compromise, then, would provide an account of the causal processes that generate these three kinds of effects.

I cannot offer such an elaborated theory. What I will do is propose some relatively speculative hypotheses about the way certain developments in contemporary capitalism may be affecting the first of these elements in the model of class compromise, the overall shape of the reverse-J curve at the heart of the model. Specifically, I will focus on the possible impact of increasing international competition and globalization of capital on the shape of the curve. 
For purposes of understanding the changing conditions for positive class compromise, the critical part of the curve in figure 7 is the upwardsloping segment in which working-class associational power positively helps capitalists solve various kinds of collective action and coordination problems. Figure 15 presents a set of tentative hypotheses about how globalization and increasing international competition might affect the relationship between workers' power and capitalists' interests within each of the three institutional spheres of class compromise.

Consider first the effects of globalization on the sphere of exchange. One of the standard arguments in discussions of globalization is that the increasing mobility of financial capital and globalization of markets has undermined the "Keynesian" solutions to macroeconomic problems in advanced capitalism. To the extent that the market for the commodities of capitalist firms are increasingly global, the realization of the economic value of those commodities depends less upon the purchasing power of workers in the countries within which those firms are located. Furthermore, heightened international competition and the constant threats by employers to move production abroad has served to reduce wage pressures, thus reducing the positive effect of strong unions on the problem of wage restraint. The positive effects on capitalists' interests of strong, centralized labor unions has thus probably been reduced by globalization. While there may still be some positive value for capitalists of a strong labor movement in terms of collective action problems of predictable, well-ordered labor markets, especially with respect to the problem of skill formation, nevertheless it seems that, on balance, globalization is likely to depress the positive slope of the first curve of figure 15.

Globalization may have quite different effects in the sphere of production. The characteristic form of working-class associational power within production are works councils and other forms of organized workers' representation within the process of production. As already noted, strong works councils may serve employer interests in a variety of ways: they may increase productivity through greater worker loyalty; they may help spot problems and improve quality control; they may increase the willingness of workers to accept flexible job classifications and work assignments; and they may facilitate the process of intrafirm skill formation. Under conditions of the intensified competition that comes from increased globalization, the positive impact of each of these effects could increase. If, therefore, there are significant untapped sources of increased productivity obtainable through enhanced cooperation at the point of production, and if working-class associational power within production facilitates such cooperation, then the upward-sloping part of the class compromise curve 


\section{SPHERE OF EXCHANGE}

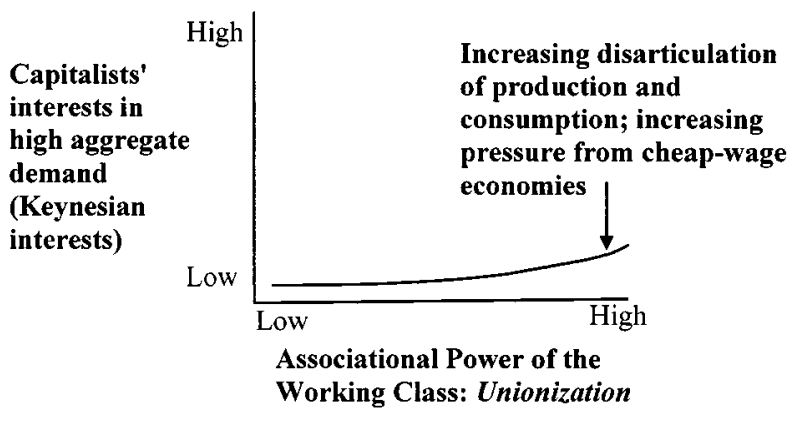

\section{SPHERE OF PRODUCTION}
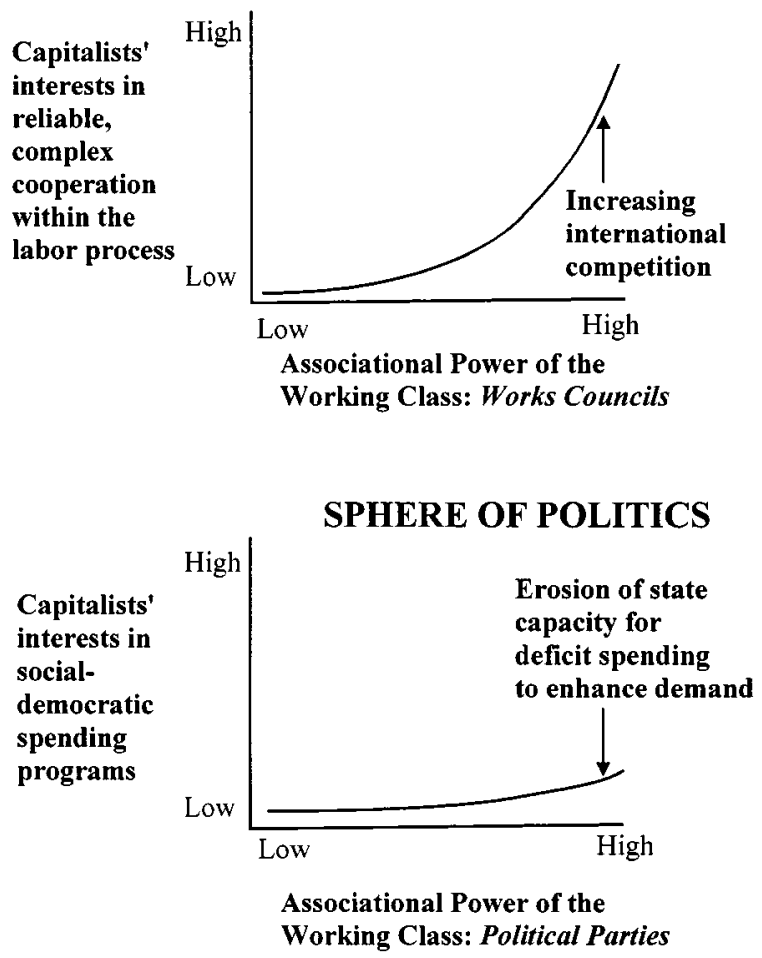

FIG. 15.-Hypothesized effects of globalization and increasing competition of the class compromise curves in the spheres of exchange, production, and politics. 
within the sphere of production may rise more steeply as a result of increased competitive pressures. ${ }^{22}$

The extent to which these effects on the prospects of positive class compromise in the sphere of production occur depends upon the nature of technology, the labor process, and the organization of work. As Streeck (1991, 1992), Aoki (1988), and others have argued, the maximally productive use of advanced technologies often requires higher levels of information coordination, problem solving, and adaptability than in traditional mass production. To the extent that strong working-class associational power within the sphere of production enhances the levels of trust between employees and managers, and such trust is necessary for such new forms of work organization, the positive effect of workers' power on capitalists' interests may be strengthened. On the other hand, if the technological conditions of production foster weak interdependencies among workers within highly atomized labor processes, increased globalization and competitive pressures would probably not enhance the positive effects of workers' associations within production. This suggests that there are probably strong interactive effects (rather than merely additive effects) of globalization and technological change on the conditions for class compromise within production.

Perhaps the most commonly told story about the negative effects of globalization on the prospects of positive class compromise concerns the sphere of politics. Because of the heightened international mobility of capital, especially financial capital, the argument goes, the capacity of states to engage in deficit spending and other reflationary policies has eroded (Stewart 1984). One of the key ways in which a politically well-organized working class positively benefited capitalists in the past was by creating the conditions for expansive state spending programs that bolstered aggregate demand. The reduced fiscal autonomy of the state resulting from increased globalization both reduces the benefits from such policies and the capacity of the state to sustain them, and thus reduces the positive slope of the class compromise in the sphere of politics.

If these arguments are roughly correct, then this suggests that there will be a tendency under conditions of globalization for positive class compro-

\footnotetext{
${ }^{22}$ Again, just to reiterate the central argument behind the reverse- $J$ curve: works councils, like all forms of working-class associational power, also have negative effects on capitalists' interests. Works councils impose various kinds of rigidities on employers, which interfere with their capacity to unilaterally reorder production in the face of competitive pressures. The downward-sloping curve-not shown in fig. 15-might therefore descend more precipitously under conditions of intensified global competition. The claim here, then, is not that the net effect of globalization necessarily enhances the value of institutions like works councils, but simply that the positive effects become stronger.
} 
mises, if they are to occur at all, to be more heavily concentrated within the sphere of production in contrast to earlier periods in which positive class compromises were particularly institutionalized within the spheres of exchange and politics. This in turn is likely to generate tendencies toward an intensification of dualism within developed capitalist economies in which some sectors of the labor force are in a position to forge productivist class compromises while others are not.

Dualistic tendencies, of course, are not a new phenomenon. In the 1960s and 1970s there was much discussion of dual labor markets and the division between the "monopoly" and "competitive" sectors of the economy. But, in the past, class compromises within the spheres of exchange and politics sometimes had the effect of muting the effects of such dualisms. Strong unions helped to create wage norms that diffused throughout the economy, benefiting workers not in the most organized sectors, and socialdemocratic class compromises in the state underwrote a social wage that partially decommodified labor power, again benefiting all workers. The erosion of conditions for stable class compromise in the sphere of exchange and in the state, therefore, risks eroding these countervailing forces to deepening dualism.

\section{CONCLUSION}

This article has attempted to chart out a general, abstract model of class compromise in capitalist society. The core intuition builds on Gramsci's insight that in democratic capitalist societies the capitalist class is often hegemonic, not merely dominant, and this implies that class conflict is contained through real compromises involving real concessions, rather than brute force. The bottom line of the argument is that the stability and desirability of such compromises depends upon the specific configurations of power and interests that characterize the relationship between the capitalist class and the working class: when it is the case that working-class associational power positively contributes to solving problems faced by capitalists, then such compromises will be much more durable than when they emerge simply from capacity of workers to impose costs on capitalists.

The theory of class compromise proposed here is thus in keeping with the traditional core of Marxist theory in arguing that the power and struggle are fundamental determinants of distributional outcomes in capitalist societies. But contrary to traditional Marxist ideas on the subject, the model also argues that the configuration of capitalist and worker interests within the "game of class struggle" is not simply determined by capitalism itself, but depends upon a wide variety of economic, institutional, and political factors. Above all, the model argues that class power not only 
can affect the outcome of class conflict, but the nature of the game itself: whether or not the confrontation of capital and labor takes the form of a sharply polarized zero-sum conflict or an iterated prisoner's dilemma, or perhaps, a strategic context with significant assurance game features conducive to positive class compromise.

\section{REFERENCES}

Ackerlof, George. 1982. "Labor Contracts as Partial Gift Exchange." Quarterly Journal of Economics 97 (2): 543-69.

Ackerlof, George, and Janet Yellen. 1986. Efficiency Wage Models of the Labor Market. New York: Cambridge University Press.

Alchian, Armen, and Harold Demsetz. 1972. "Production, Information Costs and Economic Organization.” American Economic Review 52:777-95.

Alford, Robert, and Roger Friedland. 1985. The Powers of Theory: Capitalism, State a Democracy. Cambridge: Cambridge University Press.

Aoki, Masahiko. 1988. Information, Incentives and Bargaining in the Japanese Firm. Cambridge: Cambridge University Press.

Axelrod, Robert. 1984. The Evolution of Cooperation. New York: Basic Books.

Bartlett, Randall. 1989. Economics and Power. Cambridge: Cambridge University Press.

Bowles, Samuel. 1985. "The Production Process in a Competitive Economy: Walrasian, Neo-Hobbesian and Marxian Models." American Economic Review 75:1636.

Bowles, Samuel, and Herbert Gintis. 1990. "Contested Exchange." Politics and Society 18 (2): 165-222.

1998. Recasting Egalitarianism: New Rules for Communities, States and Markets. Vol. 3 of Real Utopias Project, edited by Erik Olin Wright. London: Verso.

Calmfors, Lars. 1993. "Centralization of Wage Bargaining and Macroeconomic Performance-a Survey." OECD Economic Studies 21 (winter): 161-91.

Calmfors, L., and J. Driffill. 1988. "Bargaining Structure, Corporatism and Macroeconomic Performance.” Economic Policy 6:13-61.

Commons, John R. (1950) 1970. The Economics of Collective Action. Madison: University of Wisconsin Press.

Crouch, Colin, and Wolfgang Streeck, eds. 1997. Political Economy of Modern Capitalism: Mapping Convergence and Diversity. Thousand Oaks, Calif.: Sage.

Doeringer, Peter, and Michael Piore. 1985. Internal Labor Markets and Manpower Analysis, 2d ed. Lexington Mass.: D.C. Heath \& Co.

Dore, Ronald. 1973. British Factory, Japanese Factory: The Origins of National Diversity in Industrial Relations. Berkeley: University of California Press.

Edwards, Richard. 1979. Contested Terrain: The Transformation of the Workplace in the Twentieth Century. New York: Basic Books.

Esping-Andersen, Gøsta. 1990. Three Worlds of Welfare Capitalism. Princeton, N.J.: Princeton University Press.

Foulkes, F. K. 1980. Personnel Policies in Large Nonunion Companies. Englewood Cliffs, N.J.: Prentice Hall.

Freeman, Richard. 1988. "Labour Market Institutions and Economic Performance." Economic Policy 6:64-80.

Garrett, Geoffrey. 1998. Partisan Politics in the Global Economy. Cambridge: Cambridge University Press. 
Glynn, Andrew. 1995. "Social Democracy and Full Employment." New Left Review 211:33-55.

Goldthorpe, John. 1982. "On the Service Class." Pp. 162-85 in Social Class and the Division of Labor, edited by Anthony Giddens and Gavin Mackenzie. Cambridge: Cambridge University Press.

Gordon, David M. 1976. "Capitalist Efficiency and Socialist Efficiency." Monthly Review 29:19-39. 1996. Fat and Mean. New York: Free Press.

Gramsci, Antonio. 1971. Selections from the Prison Notebooks, edited and translated by Quintin Hoare and Geoffrey Nowell Smith. New York: International Publishers.

Greenwald, Bruce. 1979. Adverse Selection in the Labor Market. New York: Garland Press.

Hicks, Alexander, and Lan Kenworthy. 1998. "Cooperation and Political Economic Performance in Affluent Democratic Capitalism." American Journal of Sociology 103 (6): 1631-72.

Kenworthy, Lane. 1995. In Search of National Economic Success: Balancing Competition and Cooperation. Thousand Oaks, Calif.: Sage.

Korpi, Walter. 1983. The Democratic Class Struggle. London: Routledge \& Kegan Paul.

Kotz, David. 1994. "Interpreting the Social Structure of Accumulation Theory." Pp. 51-70 in Social Structures of Accumulation, edited by David Kotz, Terrance McDonough, and Michael Reich. Cambridge: Cambridge University Press.

Nakane, Chie. 1970. Japanese Society. London: Weidenfeld \& Nicholson.

Olson, Mancur. 1982. The Rise and Decline of Nations. New Haven, Conn.: Yale University Press.

Ouchi, W. G. 1981. Theory Z: How American Business Can Meet the Japanese Challenge. Reading, Mass.: Addison-Wesley.

Pohjola, Matti. 1992. "Corporatism and Wage Bargaining." Pp. 44-81 in Social Corporatism: A Superior Economic System? edited by Jukka Pekkarinen, Matti Pohjol, and Bob Rowthorn. Oxford: Clendon Press.

Pontusson, Jonas. 1997. "Between Neo-Liberalism and the German Model: Swedish Capitalism in Transition." Pp. 50-70 in Political Economy of Modern Capitalism: Mapping Convergence and Diversity, edited by Colin Crouch and Wolfgang Streeck. Thousand Oaks, Calif.: Sage.

Przeworski, Adam. 1985. Capitalism and Social Democracy. Cambridge: Cambridge University Press.

Roemer, John. 1994. A Future for Socialism. Cambridge, Mass.: Harvard University Press.

- 1996. Equal Shares: Making Market Socialism Work. Vol. 2 of The Real Utopias Project, edited by Erik Olin Wright. London: Verso.

Rogers, Joel. 1990. "Divide and Conquer: Further 'Reflections on the Distinctive Character of American Labor Law'." Wisconsin Law Review 13:1-147.

Rogers, Joel, and Wolfgang Streeck. 1994. "Productive Solidarities: Economic Strategy and Left Politics." Pp. 128-45 in Reinventiung the Left, edited by David Miliband. Cambridge: Polity Press.

Rowthorn, Bob. 1992. "Corporatism and Labour Market Performance." Pp. 82-131 in Social Corporatism: A Superior Economic System? edited by Jukka Pekkarinen, Matti Pohjol, and Bob Rowthorn. Oxford: Clendon Press.

Schmitter, Philippe. 1988. "Corporatism is Dead! Long Live Corporatism! Reflections on Andrew Schonfield's Modern Capitalism." Government and Opposition 24:5473.

Schmitter, Philippe, and G. Lembruch, eds. 1979. Trends towards Corporatist Intermediation. London: Sage. 


\section{American Journal of Sociology}

Shapiro, Carl, and Joseph Stiglitz. 1984. "Equilibrium Unemployment as a Worker Discipline Device." American Economic Review 74:203-24.

Sorensen, Aage. 1994. "Forms, Wages and Incentives." Pp. 504-28 in Handbook of Economic Sociology, edited by Neil Smelser and Richard Swedberg. Princeton, N.J.: Princeton University Press.

Soskice, David. 1990. "Wage Determination: The Changing Role of Institutions in Advanced Industrialized Countries." Oxford Review of Economic Policy 6:36-61.

Stewart, Michael. 1984. The Age of Interdependence. Cambridge, Mass.: MIT Press.

Streeck, Wolfgang. 1991. "On the Institutional Conditions for Diversified Quality Production." Pp. 21-61 in Beyond Keynesianism: The Socio-Economics of Production and Employment, edited by E. Matzner and W. Streeck. London: Edward Elgar. 1992. Social Institutions and Economic Performance: Studies of Industrial Relations in Advanced Capitalist Economies. Newbury Park, Calif.: Sage.

Streeck, Wolfgang, and Philippe Schmitter. 1985. "Community, Market, State-and Associations? The Prospective Contribution of Interest Governance to Social Order." European Sociological Review 1:119-38.

Waldman, Michael. "Job Assignments, Signaling and Efficiency." Rand Journal of Economics 15:255-67.

Williamson, Oliver. 1985. The Economic Institutions of Capitalism. New York: Free Press.

Wright, Erik Olin. 1985. Classes. London: Verso.

1997. Class Counts: Comparative Studies in Class Analysis. Cambridge: Cambridge University Press. 